\title{
WestVirginiaUniversity
}

THE RESEARCH REPOSITORY @ WVU

Graduate Theses, Dissertations, and Problem Reports

2019

\section{The "organ-accompanied solo motet" in in La Maîtrise,}

\section{7-1861}

John David O'Donnell

West Virginia University, jdodonnell@mix.wvu.edu

Follow this and additional works at: https://researchrepository.wvu.edu/etd

Part of the Music Performance Commons

\section{Recommended Citation}

O'Donnell, John David, "The "organ-accompanied solo motet" in in La Maîtrise, 1857-1861" (2019). Graduate Theses, Dissertations, and Problem Reports. 3906.

https://researchrepository.wvu.edu/etd/3906

This Problem/Project Report is protected by copyright and/or related rights. It has been brought to you by the The Research Repository @WVU with permission from the rights-holder(s). You are free to use this Problem/Project Report in any way that is permitted by the copyright and related rights legislation that applies to your use. For other uses you must obtain permission from the rights-holder(s) directly, unless additional rights are indicated by a Creative Commons license in the record and/ or on the work itself. This Problem/Project Report has been accepted for inclusion in WVU Graduate Theses, Dissertations, and Problem Reports collection by an authorized administrator of The Research Repository @ WVU. For more information, please contact researchrepository@mail.wvu.edu. 
The "organ-accompanied solo motet" in La Maîtrise, 1857-1861

\title{
John David O'Donnell
}

\author{
Project submitted \\ to the College of Creative Arts \\ at West Virginia University \\ in partial fulfillment of the requirements for the degree of \\ Doctor of Musical Arts in \\ Voice Performance
}

Nicholas Perna, D.M.A., Chair
Andrew Kohn, Ph.D., Co-Chair
William Koehler, D.M.A.
Alison Helm, M.F.A.
Department of Voice

Morgantown, West Virginia

2019

Keywords: La Maîtrise, solo motet

Copyright 2019 John David O'Donnell 


\begin{abstract}
The "organ-accompanied solo motet" in La Maîtrise, 1857-1861
\end{abstract}

\title{
John David O'Donnell
}

In his work, Motets for One Voice by Franck, Gounod, and Saint-Saëns, Richard Benefield began the scholarly study of a unique body of repertoire, the organ-accompanied solo motet repertoire of nineteenth century France. While Benefield chose to restrict his project to the work of only three major composers, he indicated other collections of Latin texted solo motets, one of which was the solo motets published in the Parisian church music journal La Maitrise, between 1857-1861. These songs are examined in terms of historical context, musical features, and possible contemporary uses.

As France recovered from the ravages of the Revolution, the French Catholic church began to rebuild its physical, pedagogic, and musical structures. Replacing instruments destroyed in the Revolution, Cavaillé-Coll developed the French Romantic organ, while French scholars researched and restored the historic Gregorian chants. A new generation of French organists, composers, and church musicians were trained at the Paris Conservatoire and at the newly founded École de musique classique et religieus by professors such as François Benoist and Louis Niedermeyer. Although the operatic style dominated church music, a new, more serious style began to develop, influenced by the works of the Renaissance polyphonic and German Baroque composers.

The solo motets of La Maitrise are composed in a variety of styles, illustrating the tensions that still remained in mid-nineteenth century France but which gave rise to some of the major developments in church music during the nineteenth century. However, the songs present a variety of possible uses to vocal performers and pedagogues today. From introducing young singers to Latin diction to expanding the solo vocal literature available for the bass voice and church musicians, the motets of La Maitrise are a versatile collection comprising only a portion of the organ-accompanied solo motet repertoire that is yet to be examined. With additional collections of motets to be examined and a variety of related topics and musical repertories, the organ-accompanied solo motets in La Maîtrise present a starting-point for many lines of future research. A unique repertory, cultivated in a time or extraordinary change, the organaccompanied solo motets of La Maitrise are a compelling collection that is well worth investigating by the singing community. 
To my wife 


\section{CONTENTS}

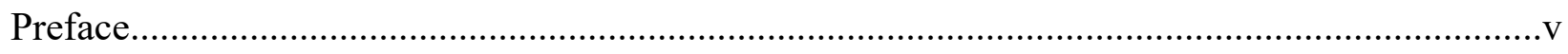

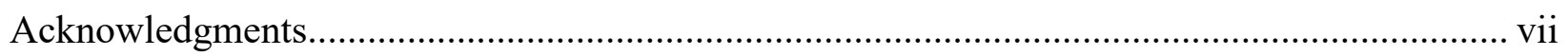

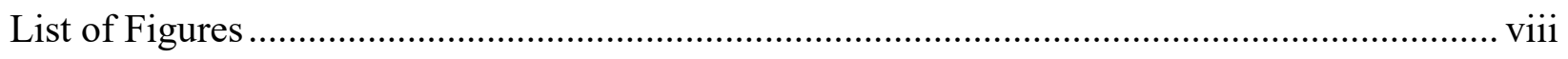

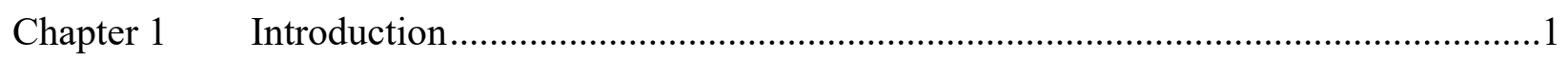

Chapter 2 Change and identity in nineteenth century French church music ..........................5

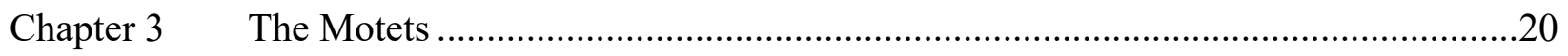

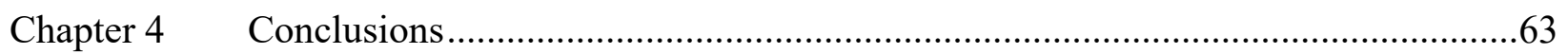

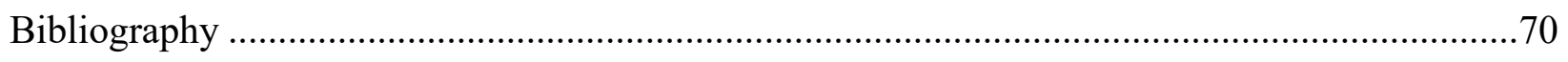

Appendix A Texts and Translations............................................................................... 76 


\section{PREFACE}

I have been interested in solo motets since I began singing at Our Lady of Victory Church in Rochester, NY in 2010. In addition to cantoring the liturgical chants and hymns at masses, I was allowed to sing a solo song at communion. After nearly wearing out Franck's Panis angelicus and the most famous Ave Maria settings, I began to search for more repertoire. Ransacking the internet and the Eastman School of Music's Sibley Library, I discovered Charles Gounod's Chants sacrés and various solo motets by Camille Saint-Saëns, Gabriel Fauré, and other French masters. These motets were of varying levels of complexity and musical interest, but they all shared a common trait: they fit the mood of traditional Catholic liturgy. They were well received by the congregation and clergy at Our Lady of Victory.

One of the sources I found at this time was Richard Benefield's then newly published work, Motets for one voice: the organ-accompanied solo motet in nineteenth-century France. This was a newly engraved edition of scores by the three French composers mentioned above. I looked at a sample of the scores on Google books and made a note that I should purchase a copy sometime. Years passed, however, before I ever saw a physical copy of the book. Then, some eight years after first discovering Benefield's book, I checked out a copy through West Virginia University libraries. I got the score simply because I was interested in possibly singing some of the music, but once I began reading the introductory essay Benefield included, I began to realize that organ-accompanied solo motets were a potential area of research that could combine two of my passions: Catholic church music and solo vocal literature.

Up to this point I had been unsuccessfully searching for a topic for my doctoral project, but organ-accompanied solo motets appeared to present a fascinating possibility. I began to 
research one of the lists of repertoire that Benefield offered but had not examined: the solo motets in La Maîtrise. My researched opened to me the fascinating world of nineteenth century France, full of revolutions and barricades, operas and organs, and the continual church music struggle of popular versus traditional music.

In this paper, I have endeavored to show how these solo motets were representative of some larger trends in nineteenth century French culture, church history, and music. I hope that by examining these motets, some previously forgotten repertoire is brought to light, and that church musicians, voice pedagogues, and lovers of song will benefit from their use. 


\section{ACKNOWLEDGMENTS}

A number of people have been most helpful, not only in my work on this doctoral project, but also throughout my journey toward completion of my doctoral degree. My advisor for this project and doctoral committee chair, Dr. Nicholas Perna, has provided essential support and encouragement as a mentor throughout my doctoral studies, even when separated by many hundreds of miles. Committee member Alison Helm and former committee member Dr. Travis Stimeling have been ever helpful in offering support and committee member Dr. William Koehler has been a valuable resource on vocal matters. Dr. Andrew Kohn, committee co-chair, has been especially patient and supportive throughout my doctoral exams and the preparation of this paper. Lastly, my thanks is due to Robert Chafin, voice professor and technician, who, by his encouragement at a crucial moment in my studies and his youthful enthusiasm for vocal art, ensured that I would rediscover my own voice and continue my vocal development. 


\section{TABLE OF FIGURES}

Figure 1.1 Solo Motets Published in La Maîtrise ............................................................2

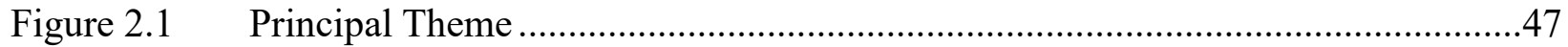




\section{CHAPTER 1}

\section{INTRODUCTION}

Having recovered from the ravages of the Revolution, French music began to blossom anew in the mid-nineteenth century as French composers began to create and explore new genres. Although opera dominated the musical life of mid-nineteenth century France, and in particular, Paris, other genres of vocal music were developed as well. One of the most discussed genres is the mélodie, art song rivaling and drawing inspiration from the German Lied. However, a parallel, largely unexamined genre was developing in church music. Richard Benefield, in his work, Motets for One Voice by Franck, Gounod, and Saint-Saëns, began the scholarly study of this unique body of repertoire, which he termed the "organ-accompanied solo motet."

Featuring sacred Latin texts and composed for solo voice with organ accompaniment, these songs are distinct from other French genres for solo voice such as the romance and mélodie in a number of respects. Yet they have been left largely unexamined. Benefield describes the problem:

The genre... has not been the topic of scholarly discourse. The compositions that comprise its repertoire are not identified as such in the works lists of the composers who wrote such pieces. In fact, the extensive church music repertoires of many nineteenth-century composers have been virtually ignored by scholars preoccupied with operatic and symphonic compositions. And it must be observed that all of France's important church music composers of the nineteenth century composed in the genre. ${ }^{1}$

Benefield's seminal work on the genre pointed out its principal features, especially how

1 Richard Benefield, Motets for one voice: the organ-accompanied solo motet in nineteenth-century France. (Middleton, Wisconson: A-R Editions, 2003), ix. 
the motets met liturgical, social, and economic needs in nineteenth-century France. While he only examined the works of three major French nineteenth century composers, Benefield did describe other collections in this genre. One such collection is the twenty-two organaccompanied solo motets found in one of the leading publications of the French church music revival, the journal La Maîtrise. Although he provided a table outlining the solo motets published in La Maîtrise, Benefield did not examine them in any way.

Figure 1.1 Solo Motets Published in La Maîtrise ${ }^{2}$

Solo Motets Published in La Maîtrise

\begin{tabular}{|c|c|c|c|}
\hline Issue $^{a}$ & Composer & Title & Voice \\
\hline Vol. 1 (1857-58) & $\begin{array}{l}\text { L. Niedermeyer } \\
\text { F. Halévy } \\
\text { L. Niedermeyer }\end{array}$ & $\begin{array}{l}\text { Ave Maria } \\
\text { Ave Maria (Salut) } \\
\text { O salutaris (Salut) }\end{array}$ & $\begin{array}{l}\text { soprano or tenor } \\
\text { soprano } \\
\text { tenor or soprano }\end{array}$ \\
\hline Vol. 2 (1858-59) & $\begin{array}{l}\text { L. Niedermeyer } \\
\text { Léonce Cohen } \\
\text { Charles Magner } \\
\text { Fr. Bazin } \\
\text { Lefébure-Wély } \\
\text { A. Vandenheuvel }\end{array}$ & $\begin{array}{l}\text { O salutaris } \\
\text { Ave Maria } \\
\text { Ave Maria } \\
\text { Pie Jesu } \\
\text { O salutaris } \\
\text { Agnus Dei }\end{array}$ & $\begin{array}{l}\text { soprano or tenor } \\
\text { tenor or soprano } \\
\text { mezzo soprano or baritone } \\
\text { bass } \\
\text { bass } \\
\text { soprano }\end{array}$ \\
\hline Vol. $3(1859-60)$ & $\begin{array}{l}\text { F. Benoist } \\
\text { Ed. Hocmelle } \\
\text { L. Valancourt } \\
\text { A. Limnander } \\
\text { F.-A. Gevaert } \\
\text { Anonyme } \\
\text { A. Hénon } \\
\text { Anonyme } \\
\text { F. Benoist }\end{array}$ & $\begin{array}{l}\text { Ave Maria } \\
\text { Tantum ergo } \\
\text { Sub tuum praesidium } \\
\text { Salve Regina } \\
\text { O salutaris } \\
\text { Sanctus } \\
\text { Pie Jesu } \\
\text { Sanctus } \\
\text { O salutaris }\end{array}$ & $\begin{array}{l}\text { mezzo soprano } \\
\text { baritone } \\
\text { mezzo soprano or baritone } \\
\text { solo voice } \\
\text { soprano } \\
\text { solo voice } \\
\text { soprano } \\
\text { solo voice } \\
\text { solo voice }\end{array}$ \\
\hline Vol. 4 (1860-61) & $\begin{array}{l}\text { Ed. Batiste } \\
\text { Edouard Batiste } \\
\text { Jule Cohen }\end{array}$ & $\begin{array}{l}\text { Ave Maria } \\
\text { O salutaris } \\
\text { O salutaris }\end{array}$ & $\begin{array}{l}\text { soprano, tenor, or baritone } \\
\text { tenor or soprano } \\
\text { soprano or tenor }\end{array}$ \\
\hline
\end{tabular}

a. In the first two years, the printed music section of this journal was called La Maitrise. In the third and fourth years, the printed music portion of the publication was divided into two sections: Grande Maitrise and Petite Maitrise. Music published included old masters' and contemporary composers' works for one or more solo voices, chorus, grand organ, and organ or harmonium.

However, these songs, published between 1857-1861 at the turning point of the French sacred music revival, demonstrate the transition from the operatic culture of early nineteenth century France, to the more serious church music culture cultivated by French musicians in the second

2 Benefield, Motets for one voice, xii 
half of the nineteenth century.

This project focuses on bibliographic research, referencing works on a variety of topics applicable to nineteenth century France, such as musical culture, organs and organists, vocal music, the Gallican-Ultramontane controversy, and developments in sacred music. While most of these resources were in English, a select few sources in French were used. Chief among these was the Biographie universelle des musiciens by François-Joseph Fétis. A period biographical dictionary, this work was one of the only places where biographical details could be found about some of the obscure composers who contributed motets to this collection.

Unfortunately, there was no written information about this collection of motets to be found in the articles of La Maîtrise itself. In addition to published scores, the journal offers a variety of written material: editorial articles on sacred music topics; polemical essays on the virtues of Gregorian chant; lists of new church music published in France; reviews of contemporary performances; and reports from church music conferences. However, there are no reviews of the music published as part of the journal, or any reference to it, aside from a listing of the pieces on the front page. Consequently, the articles of the journal itself, while offering some insight into the church music philosophy espoused by the journal's editors, were left unexamined, preference being given to English language sources which summarized the goals of the church musicians involved.

This project will discuss the songs in terms of their musical style, structure, features of the vocal line, text setting, and nature and features of the accompaniment. It will examine three forces that led to their creation:

- the search for a distinct sacred music idiom;

- the rebuilding of church music programs through education and the construction of new 
organs;

- and the explosion of the music publishing industry.

In addition to contextualizing the motets, this project will demonstrate whether the motets participated in the popular operatic style of the early nineteenth century, or whether they anticipated the more serious style of the latter half of the century. At the conclusion of this discussion, some indications will be offered as to the suitability of these motets for use in present pedagogical and performance contexts. 
CHAPTER II

CHANGE AND IDENTITY IN NINETEENTH-CENTURY FRENCH CHURCH MUSIC

\section{Revolution and recovery}

Beginning in 1789, all aspects of French life were rent asunder by the Revolution. To say that the Revolution issued in an era of upheaval and dramatic change does not begin to describe the cataclysmic rift that was created between pre-Revolutionary and nineteenth century France. As Ochse describes it, "the French Revolution was like a great tidal wave that permeated every aspect of daily life."1 The monarchical and feudal system that had governed France for centuries was swept away, and along with it the official state religion, the Gallican Catholic Church. Such upheaval cannot continue for long, and in the nineteenth century, the French sought to find a stable, modern identity, a process that was characterized by a continual struggle with its historical Catholic and more recent Revolutionary past.

Nowhere is this more evident than in the field of church music. Following the Revolution, everything had to be rebuilt, from church music repertoire, pedagogy, and liturgy, to pipe-organs, and including the grandfather institution of all Catholic musical traditions, Benedictine monasticism. Everything had been washed away by Revolutionary fervor, and rebuilding was a slow process.

As the state-established religion of the Kingdom of France, Catholicism was one of the primary targets of the enlightenment revolutionaries. Early in the Revolution, all church property was seized by the state. ${ }^{2}$ Priests and religious were heavily persecuted, and Catholicism was

1 Ochse, Orpha. Organists and Organ Playing in Nineteenth-Century France and Belgium. (Bloomington, IN: Indiana University Press, 1994), 3.

2 Ibid. 
replaced with various concocted enlightenment religions such as the "Cult of Reason." Iconoclasm swept through France, and as the religious decorations of French churches were looted or destroyed, many pipe organs were similarly abused. Of the two thousand organs estimated to exist in France at the start of the Revolution, only a few hundred survived. With all church property held by the state, the surviving instruments were either repurchased by parishes or church wardens, or used for Revolutionary government events. ${ }^{3}$

As the French Church struggled to rebuild throughout the nineteenth century, it faced a multiplicity of problems. The first was its dependency on the government, which now owned all church property and paid all church salaries. ${ }^{4}$ As this arrangement persisted throughout the nineteenth century, church leadership was anxious to cultivate positive relationships with the bureaucrats who controlled the money. A second pressing problem was a shortage of priests. During the Revolution, many priests had been killed, exiled, or left the priesthood, and the remaining clergy were aging. ${ }^{5}$ It was difficult to recruit young men, for French society was now far more secular, priests were isolated and overworked, and bishops had nearly complete autonomy over priest's lives. Thirdly, seminary education was in disarray, with the average seminary education "offering a plain course with the minimum of intellectual demands," which also contributed to the quality of men attracted to the priesthood. ${ }^{6}$ Finally, the ultramontane movement - which saw closer identification with Rome and the Roman pontiff as the solution to the theological and social challenges of the nineteenth century - caused French church hierarchs to abandon French independence in matters of ecclesiology and liturgy, leading to increased

Ochse, Organists and Organ Playing, 3-4.

Ibid., 2.

5 Austin Gough, Paris and Rome: The Gallican Church and the Ultramontane Campaign 1848-1853. (Oxford: Clarendon Press, 1986), 2.

6 Ibid., 5. 
friction with the increasingly secular French government. The government, which in the postRevolutionary era owned all church property and paid all clergy salaries, saw Roman influence upon the French church as the intervention of a foreign power.

French church music faced similar struggles as it sought to climb out of the desolation left by the Revolution. Along with the destruction of church organs, the sacred music education system had been decimated. Under the monarchy, church musicians were primarily trained by a maîtrise or church choir school, a system which had persisted since the middle ages. ${ }^{7}$ With the closure of religious houses and churches, these institutions had been eliminated and music training was available only in the secular sphere.

Consequently, church music, which consisted of chant and organ music, was quite deplorable in the three decades following the Revolution. The chant limped along to the accompaniment of the unique instrument, the serpent, while organ music was mostly in the style of popular airs and operatic tunes. Almost none of the music was contrapuntally conceived. Organists and organ technique had virtually died out for lack of training, leaving only pianists playing music that varied little from the salon to the cathedral. ${ }^{8}$ Church music needed reforming and the nineteenth century saw many developments in France as chant was restored, music schools were founded, organ technique revised, and many new organs built.

\section{Chant Reformed}

A reform of Gregorian chant was approached from several quarters. In 1855, an influential treatise on organ accompaniment of chant was published by church music pedagogue

7 The Oxford Dictionary of Music, s.v. "maittrise," accessed February 27, 2019, http://www.oxfordreference.com.www.libproxy.wvu.edu/view/10.1093/acref/9780199578108.001.0001/acref9780199578108-e-5736.

8 Ochse, Organists and Organ Playing, 121-124. 
and composer Louis Niedermeyer and music critic Joseph d'Ortigue. ${ }^{9}$ The new Benedictine monastery at Solesmes began rigorous research into medieval chant manuscripts, culminating in the publication of a restored chant edition for the first time since Renaissance alterations to the melodies. Medieval manuscripts were painstakingly photographed and studied, and long melismatic passages were restored in the chant melodies. ${ }^{10}$ With some variation, Solesmes melodic reconstructions were eventually adopted by Rome and published as the Vatican Graduale Romanum in 1908.

By the time the Vatican Graduale was published, the Roman hierarchy had come to exert significant influence in French ecclesiastical affairs. At the time of the Revolution, the church of France had long enjoyed certain privileges in its relationship with the Holy See. Most of these related to church governance, the French monarchy and French bishops exercising a large degree of autonomy from Rome. French dioceses were allowed their own liturgical "rites," or order and texts for saying the mass and Divine Office. Preeminent among these rites was the Rite of Paris. Especially important from a musical standpoint, the Parisian Rite prescribed the points in the service where the organ would play. ${ }^{11}$ Lueders outlines how the organ was to provide alternatim versets for the mass Ordinary, as well as an entrée for the beginning of mass, an offertory, elevation, communion, and sortie as recessional. ${ }^{12}$ The alternatim practice, well beloved of organists as guarantor of job security, allowed the choir to leave out alternate sections of the ordinary chants, and for the organist to instead provide music based in some way upon the chant.

9 Louis Niedermeyer and Joseph d'Ortigue, Gregorian Acccompaniment. Translated by Wallace Goodrich. (New York, London, Chicago: Novello, Ewer \& Co., 1905).

10 Katherine Bergeron, Decadent Enchantments: The Revival of Gregorian Chant at Solesmes. (Berkeley: University of California Press, 1998).

11 Ochse, Organists and Organ Playing, 127.

12 Kurt Lueders, "Revisiting Parisian Organ Culture from the Long Nineteenth Century: Models for Renewal in a Challenging Context for Religion?" Liturgical Organ Music in the Long Nineteenth Century. Edited by Peter Peitsalo, Sverker Jullander, and Makus Kuikka. (Helsinki: Sibelius Academy, University of the Arts Helsinki, 2017), 26. 
This would all come to an end in the nineteenth century with the success of the ultramontane movement and the adoption of the Roman Rite throughout France. The term ultramontane, or "beyond the mountains" referring to the pope residing on the other side of the Alps in Italy, had been used for centuries, but in the nineteenth century it became the name for a movement that sought to bring the French church into greater unity with Rome. This necessitated a conflict with the Gallican faction, who supported the historical independence of the French church. The "conflict," Gough explains, was "between the belief that the challenges of postRevolutionary society could be met only by a centralized Church, uniform in doctrine, style, and discipline, controlled by an infallible Pope and a vigilant Roman administration, and the contrary belief that the Church would lose all influence in modern society unless it had deep roots in national character and local institutions, and a looser, federal, collegial structure." ${ }^{13}$ The other party in the conflict were the secular French post-revolutionary governments, for the fall of the Catholic French monarchy had precipitated a long battle between Church and state.

The ultramontanist faction prevailed, with papal infallibility declared by the First Vatican Council in 1870 . However, years before this, "between 1848 and 1853 the French dioceses had been compelled to give up their local liturgies and adopt the" Roman liturgy. ${ }^{14}$ This necessitated a major paradigm shift in French church music. French diocesan liturgies had long allowed most of the chants of the mass to be sung after the alternatim practice wherein the choir would alternate verses or portions of the text with the organ. The choir would sing its portions of text to the Gregorian chant melodies from the architectural choir in the front of the church, while the grand orgue at the back of the church would "sing" its verses to composed or improvised music

3 Gough, Paris and Rome, vi.

14 Ibid. 
that was ostensibly related to the chant melody it was replacing.

The Roman liturgy did not allow for alternatim practice and required the choir to sing the chants in full. In France, organ versets became emblematic of the Gallican style; Gregorian chant was championed by the ultramontanists. Solesmes monastery, founded by ultramontanist leader Prosper Guéranger (1805-1875), would in later years become the epicenter of Gregorian chant; in the mid-nineteenth century it was enough that "plainchant... might be actually the most important element of the liturgical revival; the long line of Gregorian melody echoing in the towering spaces of one of the ancient cathedrals created an almost magical evocation of a medieval age of faith." 15

French organists felt understandably left out in the cold. With organ versets at the grand orgue replaced by the "restored" plainchant, the principal portion of the titulaire, or principle, organist's work would disappear. The titulaire only played the parts of the service outlined above on the main organ located almost always at the west end of the nave and did not accompany any of the singing. ${ }^{16}$ Singing was handled by a lesser keyboardist on the choir organ located in the choir or east end of the church. The reduction in playing time necessitated by the singing of the chants still made an impression on organists such as Saint-Saëns, who years later in 1913 could still offer a sideways remark on how the organ "was reduced to short interludes." 17

Not everyone was in a hurry to adopt Gregorian chant. As music critic Paul Scudo expressed it, "it was hard to believe... that the monotonous chanting of half-understood Latin was superior either aesthetically or morally to the performance of a motet by Mozart; one might as

15 Ibid., 164.

16 Lueders, "Revisiting Parisian Organ Culture," 26.

17 Camille Saint-Saëns "La Prononciation du latin dans l'Église de France," École Buissonnière (Paris: Lafitte, 1913), 177-186; Quoted in Rollin Smith, Saint-Saëns and the Organ. (Stuyvesant, NY: Pendragon Press, 1992), 212. 
well say that the crude pictures of saints sold at church doors were better than Michelangelo's Pieta."18 Saint-Saëns expressed similar sentiments in response to the 1903 papal Moto propriu on sacred music. Writing in 1913, he lamented that "in art, holiness is not sufficient. Talent is necessary, Style is necessary. And where will great style find refuge if not in church." ${ }^{19}$ However, Gregorian chant was here to stay, and it became a major influence on subsequent generations of French church musicians, both in exposing them to modal sonorities (Fauré), and as material for composition (Tournemire). ${ }^{20}$

\section{New schools and new organs}

Along with the chant restoration and other efforts to improve the musical repertoire, it was necessary to tackle the equally difficult task of training new church musicians. Alexandre Choron (1771-1834), who founded the Institution royale de musique in 1817, led the first effort to restore church music education. A "spokesman for the Catholic musical heritage," Choron was the first to seek to cultivate a sacred style, emphasizing Gregorian chant and renaissance polyphony. ${ }^{21}$ Although Choron's government funded school was eliminated amidst the religious upheavals of the 1830 s and 40s, Louis Niedermeyer was able to re-open it in 1853 as the École de musique classique et religieus, whereby Niedermeyer became one of the leading figures in the church music reform effort. Fully funded by the government, the École Niedermeyer offered full scholarships, was supported by the Parisian bishops, and counted among its graduates such

18 Gough, Paris and Rome, 164.

19 Camille Saint-Saëns, "Music religieuse," École Buissonnière (Paris: Lafitte, 1913), 159-67; Quoted in Rollin Smith, Saint-Saëns and the Organ. (Stuyvesant, NY: Pendragon Press, 1992), 204.

20 Camille Saint-Saëns, "Music in the Church," The Musical Quarterly (January 1916), 1-8; Quoted in Rollin Smith, Saint-Saëns and the Organ. (Stuyvesant, NY: Pendragon Press, 1992), 218.

21 Ralph P. Locke, "Paris: centre of intellectual ferment." The Early romantic era: between revolutions, 1789 and 1848. Edited by Alexander L. Ringer. (Englewood Cliffs, NJ: Prentice Hall, 1991), 41. 
illustrious figures as Gabriel Fauré, Camille Saint-Säens, and Eugene Gigout.

French organ technique, which had foundered in the wake of the Revolution, was reawakened by the teaching of Benoist at the Paris Conservatory and subsequently by Fétis and Jacques Lemmens at the Brussels Conservatory. The latter two pedagogues thought highly of German organ playing, centered as it was on J.S. Bach and pedal technique. ${ }^{22}$ Lemmens, known as foremost pedal technician of his generation, passed on the importance of pedal work to influential graduates of the Brussels Conservatory such as Guilmant and Widor. $^{23}$

Perhaps even more important than training new organists and church musicians, was the task of building new French organs. The devastations wrought on French church organs by the Revolution left room for one of the greatest creative explosions in the long history of the pipe organ, and this explosion is connected to one iconic name: Cavaillé-Coll. Aristide Cavaillé-Coll sprang upon the Parisian church music scene in 1833 at the age of twenty-two, receiving contracts for the two most important organ projects in Paris. His influential career would span the rest of the century, creating the French Romantic organ and propelling forward the careers of organists with whom he was associated.

Cavaillé-Coll created the French Romantic organ by means of several revolutionary organ building developments. One was the introduction of the Barker lever, a device which allowed organ keyboards to respond almost as lightly as a piano keyboard, no matter how much air resistance was being used to make the pipes sound. This device was used even in CavailléColl's first major organ, that of Saint-Denis, completed in 1841, and allowed rapid passage-work even with the organ at great volume. He cultivated a Romantic, orchestral sound for the pipe

22 Ochse, Organists and Organ Playing, 165.

23 François Sabatier, "Lemmens, Jacques-Nicolas," Grove Music Online. 2014, Accessed February 27, 2019, http://www.oxfordmusiconline.com.www.libproxy.wvu.edu/grovemusic/view/10.1093/gmo/9781561592630.001. 0001/omo-9781561592630-e-0000016384. 
organ, both in terms of imitating specific orchestral instruments, and in overall richness of sound. This was a significant and not always welcome development, as the classical French organ was known not for Romantic warmth, but for ringing mutation stops. Cavaillé-Coll's tonal design techniques also allowed for gradual crescendo and diminuendos while maintaining consistent tone color, something not possible on the earlier organs. ${ }^{24}$ Despite these developments, CavailléColl took pains to remain within the French tradition, maintaining the traditional stop divisions and other traditional elements.

Cavaillé-Coll's influence on Romantic era French organists was almost as great as his influence on the Romantic organ. Lefébure-Wély was one of his great friends and premiered nearly all of his new organs, frequently performing concerts on new instruments for royalty or distinguished guests before the actual premieres. Organ premiers were popular social events, and often drew great crowds. But not only did Cavaillé-Coll feature organists such as Lefébure-Wély at concerts, he would also help to secure them positions at churches were they could play one of his new instruments, such as Lefébure-Wély's appointment at La Madeleine or Franck's appointment at Saint-Clotilde. ${ }^{25}$ Franck was appointed even before the Saint-Clotilde organ was completed and Cavaillé-Coll changed and expanded the proposed organ significantly at the behest of Franck, at a considerable increase in cost, evidence of a great respect for the composer. Cavaillé-Coll also did much to promote the playing of Lemmons and by extension the German influenced pedal technique and legato style that Lemmons and the Belgian Conservatory school brought to bear upon French organ playing.

24 Hans Klotz and Kurt Lueders. "Cavaillé-Coll, Aristide," Grove Music Online. 2001, Accessed February 27, 2019, http://www.oxfordmusiconline.com.www.libproxy.wvu.edu/grovemusic/view/10.1093/gmo/9781561592630.001. 0001/omo-9781561592630-e-0000005199.

25 Fenner Douglas, Cavaillé-Colle and the Musicians. (Sunbury Press: Raleigh, North Carolina, 1980), 71-82, 113142. 


\section{The genesis of La Maitrise}

In the 1850 s and early 60 s, many of these developments were still in progress. However, the combination of them were slowly beginning to turn the tide in French church music. The new organs of Cavaillé-Coll, the sacred music education of the Ecole Niedermeyer, the influence of German organ technique in the playing and teaching of Lemmons, and the restoration of Gregorian chant were setting the stage for a major shift in focus in the music making in French churches. Niedermeyer, d'Ortigue and others felt that the publication of a journal advocating sacred music would be an important step in propagating their ideas on sacred music and on disseminating musical scores that were not accessible throughout France. The resulting journal was named La Maîtrise, after the pre-Revolution choir school system.

La Maîtrise was proceeded by Revue de la musique religieuse, populaire et classique, a journal published from 1845-1848 and edited by Jean-Louis-Felix Danjou, organist at SaintEustache and later at Notre Dame. ${ }^{26}$ While the Revue covered all sorts of music, La Maîtrise focused "specifically on church music." It's "primary objectives were to change the organ and choral repertoires" in France, "and the manner of singing and accompanying chant."27

The journal consisted of written articles and musical scores and was published by the Parisian firm of Huegel and Company; the scores and articles were initially published in one combined single volume. Articles in La Maitrise covered such topics as the organ in Christian worship, esthetic styles appropriate to the liturgy, and the desirability of Gregorian chant. There were also letters to the editor, reviews of concerts, and bibliographies of liturgical books and music published in France. Musical scores - which featured an identifiable title page: a picture of

\footnotetext{
Douglas, Cavaillé-Coll, 34.
}

27 Ochse, Organists and Organ Playing, 136. 
a massive organ with song information printed in the center of the pipes - were by ancient or modern masters, with a great proportion by the former: organ pieces by Bach and Renaissance vocal works by Victoria and Palestrina. The most modern master represented in the first year was Niedermeyer himself.

For the first two years of publication, Niedermeyer served as the director and founder and Joseph d'Ortigue as editor-in-chief. The two had previously collaborated on an organ accompaniment treatise and shared many of the same views. D'Ortigue had studied music and law before settling into a career as a music critic. He was a great friend of Berlioz, and even became Berlioz's successor at the Journal des débats in 1864. Particularly passionate about sacred music and liturgical plainsong, d'Ortigue's major published work was a treatise on the subject published in 1853, the Dictionnaire liturgique, historique et théorique de plain-chant. ${ }^{28}$ In year three, La Maîtrise endured a change of leadership and format. Niedermeyer departed the endeavor, leaving d'Ortigue in the role of editor in chief and director. Instead of publishing only the works of ancient and modern masters, a musical commission was established which accepted new compositions for publication in the journal and determined which would be printed. This commission consisted of Ambroise Thomas, a composer and pedagogue, François Benoist, the longtime organ professor at the Conservatoire and organist at the Imperial Chapel, and Charles Gounod, whose most prominent post at the time was the director of the Orphéon, or Paris choral society.

In the second two years of publication, the format changes entailed that the scores were published separately from the written articles. Scores were published in two collections: Grand

28 Sylvia L'écuyer, "Ortigue, Joseph (Louis) d'," Grove Music Online. 2001, Accessed September 19, 2018, http:///www.oxfordmusiconline.com/grovemusic/view/10.1093/gmo/9781561592630.001.0001/omo9781561592630-e-0000020507. 
Maîtrise - scores for large churches; and Petit Maîtrise - scores "of a style simple and severe, for the use of seminaries, convents, and of small music schools. ${ }^{29}$ Scores continued to consist of organ works, choral works, and works for solo voice and organ.

The solo vocal works in La Maitrise are of two kinds. First, there are a number of popular style melodies, with long strings of strophic verses, mostly in French and often on a subject of popular devotion, such as the Blessed Virgin Mary or the infant Jesus at Christmas. Second, there are through composed works, Latin texted motets for solo voice with organ accompaniment. The Latin texts are all liturgical texts commonly found in choral motets from the Renaissance onwards, indicating that the solo works are in some way related to the choral repertoire, either by substitution or function. They appear in the pages of La Maitrise with a frequency that indicates they were a regular and important part of nineteenth French church music. Such ubiquity is a bit surprising, for while the genre of organ-accompanied solo motet has some history going back to the seventeenth century, there is not a corresponding nineteenth century repertoire in other European schools of music. This history shall now be traced.

\section{Organ-accompanied solo motet: history and influences}

Benefield posits that the organ-accompanied solo motet genre originated firstly with Italian composer Ludovico da Viadana (1560-1627), whose Cento concerti ecclesiastici of 1602 featured solo vocal pieces for one or more singers. ${ }^{30}$ Works such as Viadana's "Versa est" and Giovanni Paolo Caprioli's (c.1580-c.1627) “Ave Regina caelorum” (1618) offer a varied vocal line over a basso continuo scored for organ. Monteverdi wrote a number of solo works in this

29 Joseph d'Ortigue and Louis Nidermeyer, ed., La Maîtrise, vol 4 (Paris: Heugel et Ce., 1860-1861).

30 Benefield, Motets for one voice, xi. 
genre, "Salve, o regina" (1624), and "O quam pulchra" (1625) being some examples.

The solo motet made it to France before the end of the nineteenth century with the publication of Guillaume Gabriel Nivers's (1632-1714) Motets à voix seule, accompagné de la basse continue et quelques autres motets à deux voix avec l'art d'accompagner sur la basse continue pour l'orgue et le clavein in 1699. Benefield notes only two other collections of solo motets published by French composers in the seventeenth and eighteenth centuries, those by André Campra (1660-1744) and Jean François Lallouette (1651-1728) in 1699 and 1726 respectively, because most French composers rarely wrote small scale solo vocal pieces. ${ }^{31}$ Their goal was to write for, or in imitation of, the royal court, so the Grand motet dominated French church music composition. These were "large-scale, cantata-like works," which interacted little with the liturgy. While the da capo aria was an important part of these Grand motets, neither compositions in the free continuo style of the Italian masters nor in the song style of the $L a$ Maîtrise motets were employed.

In the nineteenth century, a new market for the organ-accompanied solo motet began to arise out of several unrelated circumstances. One was the rise of the amateur performer, facilitated by bourgeois culture and the mass production of pianos. Another was the rise of the music publication industry, which continually provided new material for the culture to consume. Still another circumstance was the desire to have music in small churches, despite the fact that such churches frequently had no choir. Benefield suggests that solo motets helped amateur singers provide music for the liturgy. ${ }^{32}$

Solo settings of common texts would be useful at high, or sung masses, but also at low

Benefield, Motets for one voice, xi.

32 Ibid., xvii. 
masses, where music could be offered but where the prescribed texts of the mass ordinary and proper did not need to be sung. Particularly popular in France was the service of Benediction of the Blessed Sacrament, which customarily featured a Marian motet and for which the hymn $O$ Salutaris was prescribed. ${ }^{33}$ Another opportunity for solo motets was the "elevation motet," a custom unique to France, in which a motet was sung following the elevation of the consecrated Host during the Eucharistic prayer. ${ }^{34}$ Pie Jesu and $O$ Salutaris, texts which appear in this collection from La Maîtrise, were two of the most common texts for elevation motets.

Organ-accompanied solo motets could also have been quite popular in the fashionable Parisian salons. A number of those published in the pages of La Maîtrise were written in the operatic bel canto style, the popular music of early nineteenth century France. The accompaniments, while marked for organ, are often more idiomatic to the piano than to the organ. Parisian salons were frequented by a great number of the city clergy and a popular Ave Maria may have been heard by the same audience in the salon and the church. Some salons even featured organs: Saint-Saëns relates that the home of Pauline Viardot, where he regularly attended events, contained an organ by Cavaillé-Coll, and Louis Vierne relates having heard Saint-Saëns' solo motet setting of the "Inviolata" at a Viardot soiree. ${ }^{35}$

All of the major French composers of the nineteenth century - as well as many lesser ones - composed solo motets. Thus, the genre shares many characteristics with the secular vocal music written during the same era. Opera, choral music, and solo song underwent significant developments, and the mid-nineteenth century was an important time for secular as well as sacred genres. An overview of these secular genres and their characteristics is important in

33 Ibid., XV.

34 Jean-Paul Montagnier, The Polyphonic Mass in France, 1600-1780. (Cambridge: Cambridge University Press, 2017), 144.

35 Benefield, Motets for one voice, xvii. 
understanding the solo motets.

Secular solo song consisted primary of the romance, the dominant "form of French classical song in the early decades of he nineteenth century... it featured highly expressive, sentimental music... [with] little or no musical-poetic interaction between voice and accompaniment. ${ }^{" 36}$ But by the middle of the nineteenth century, the romance began to give way to the mélodie which featured a closer "synthesis between text and music." ${ }^{37}$ Just as in organ playing, music from Germany - in this case Schubert's Lieder - was an important influence on French praxis. Additionally, the development of romantic poetry and a decline in the artistic level of the romance helped to fuel the creation of the mélodie, a genre commonly considered to begin with Berlioz's Les Nuits d'été (1841). ${ }^{38}$

In the first half of the nineteenth century, opera was characterized by the bel canto music of the Italian composers - chief among them Gioachino Rossini (1792-1868). These operas, featuring the "multi-movement 'number' as the basic unit of opera," won for themselves "a permanent position around the globe," and the concept of an established repertory of operas began to take effect. ${ }^{39}$ As the century continued, changes in the opera world caused the influence of the Italian opera school to wane. Other national schools of opera gained prominence, dialogue became more and more musically important, and the new concept of opera repertory caused a waning in the influence of the impresario. However, opera still generated an enormous amount of societal interest throughout the nineteenth century, as can be seen from the amount of journalistic

36 Carol Kimball, Song: A guide to Art Song Style and Literature. (Milwaukee, WI: Hal Leonard Corporation, 2006), 158.

37 Ibid., 157.

38 Kimball, Song, 157.

39 Brown, Howard Mayer, Ellen Rosand, Reinhard Strohm, Michel Noiray, Roger Parker, Arnold Whittall, Roger Savage, and Barry Millington. 2001 "Opera (i)." Grove Music Online. Accessed February 24, 2019, http://www.oxfordmusiconline.com.www.libproxy.wvu.edu/grovemusic/view/10.1093/gmo/9781561592630.001. 0001/omo-9781561592630-e-0000040726. 
effort devoted to opera. And "the centre of this activity, at least in terms of bulk, was Paris, in which an important première at the middle of the century would stimulate as many as 20 or 30 separate reviews, many of them lengthy." 40

The nineteenth century saw the emergence of choral music as a secular genre. While organized choral music had been principally practiced in the church, secular choral movements, such as the French Orphéon, became popular in the nineteenth century as a cultural institution. Founded in Paris in 1833, "the Orphéon choral society... rapidly expanded," with a yearly concert featuring more than a thousand members. ${ }^{41}$ Their existence was an opportunity for composers and conductors: Armand Limnander, composer of a solo motet in La Maîtrise, composed for and led several choral societies in Belgium and Paris, and Charles Gounod directed the Paris Orphéon society for eight years in the $1850 \mathrm{~s}$.

Published at the height of these musical developments, the solo motets of La Maîtrise reflect the musical and ideological tensions of the era. Changing institutions, styles, and genres in French vocal music allowed for incongruous variety to appear within a repertory, and the solo motets of La Maîtrise are no exception.

40 Brown, "Opera (i)." Grove Music Online.

41 "Orphéon." Grove Music Online. 2001, accessed February 24, 2019, http://www.oxfordmusiconline.com.www.libproxy.wvu.edu/grovemusic/view/10.1093/gmo/9781561592630.001. 0001/omo-9781561592630-e-0000020492. 


\section{CHAPTER 3}

\section{THE MOTETS}

\section{Method of Analysis}

In analyzing the organ-accompanied solo motets in La Maitrise, each piece was examined in terms of a variety of musical characteristics. The characteristics of each are recorded in annotation format and each annotation is proceeded by a brief biographical sketch of the composer. When a composer contributed more than one song to the collection, all of the annotations are grouped together following a biographical sketch. A sample annotation is attached at the end of this section.

With at least sixteen composers represented in this collection - several of the motets' composers are anonymous - the composer's biographical information is important to an assessment of each motet. The composers represented in this collection exemplify a variety of different positions in the musical landscape of nineteenth century France, and some biographical information on their training and main means of employment can offer some clues as to the style of the song. For instance, Niedermeyer - as an educator and authority on chant - is quite representative of the developing sacred style; Halévy, a composer of grand opera, offers a work representative of the bel canto tradition; however Lefébure-Wély, known in his own day as the leading composer in the "light" style, offers a work in the serious style. ${ }^{1}$

In examining the songs, an annotation page containing the following ten musical characteristics was developed:

1 Ochse, Organists and organ playing, 32-33. 
- $\quad$ completeness of the text (as well as the presence of significant textual repetition);

- prominent characteristics of the vocal line;

- $\quad$ key;

- range of the vocal line as notated in the score;

- consideration of the vocal tessitura as notated in the score (which will mean that they are actually sung down an octave if notated in G clef but sung by a male voice);

- prominent characteristics of the keyboard part;

- other important musical elements;

- $\quad$ suggestions regarding potential contemporary uses for the motet;

- $\quad$ and the musical style of the work.

Three separate styles are mentioned: bel canto style, which signifies a song in the style of a bel canto opera aria; lyric operatic style, which describes a song that is highly chromatic, has a contrapuntal accompaniment, and an operatic vocal line lying between French grand opera and bel canto; and sacred style, which features a reduced chromaticism, conservative vocal lines, and keyboard part that is idiomatic to the organ.

One aspect of the motets that is not examined is the issue of historical performance practice. This issue affects these songs both in terms of the accompaniment instrument used, and the pronunciation of the Latin texts. Practical considerations dictate that modern performers will use whatever keyboard instrument is readily available, despite the fact that these songs would have first been heard on either French classical instruments, the romantic organs of CavailléColl, or even a harmonium. However, as is shown later, almost all of the songs are flexible enough to be played at the piano or any pipe organ, so historical keyboard performance of the motets was left outside the scope of this project. 
Analogously, it has been assumed that modern performers will pronounce the texts following the commonly accepted modern pronunciation. Only in true historically informed performance practice would French Latin would be used, as is markedly different from the Roman pronunciation that is standard today. If historical French Latin pronunciation is to be used, a guide for its pronunciation should be consulted. A good place to start is Anthony Reeves' article on "The Use of French Latin for Choral Music."2 However, at the time these motets were published, ecclesiastical Latin pronunciation in France was in a state of flux, for as the Ultramontanes fought to promote all things Roman, even the pronunciation of the liturgy became a topic of debate. As a result, these songs might have been pronounced with either French or Roman Latin pronunciation, depending on whether these songs were sung by someone with Ultramontane or Gallican leanings. The fact that this was a source of discord among French Catholics can be seen even as late as 1913, when Saint-Saëns wrote an article entitled "Pronunciation of Latin in the French Church," complaining that the imposition of all things Roman upon the Church of France would ruin devotion and inspiration. ${ }^{3}$

Following the sample annotation, the subsequent pages will present the composer biographies and the annotations alphabetically by composer, starting with Édouard Batiste and ending with the anonymous contributions. Either one biography or one annotation will be presented per page.

Anthony R. Reeves, "The Use of French Latin for Choral Music.” Choral Journal, 42 (October 2001), 9-15. Camille Saint-Saëns, "La Prononciation du latin;” Quoted in Smith, Saint-Saëns, 210-216. 
Sample annotation

"Song title"

1. Text:

2. Voice Part:

3. Key:

4. Range:

5. Tessitura:

6. Style:

7. Vocal Characteristics:

8. Keyboard Characteristics:

9. Important Musical Elements:

10. Potential Uses: 


\section{Édouard Batiste}

As his musical talent was evident from a young age, Édouard Batiste (1820-1876) entered the Paris Conservatoire at age eight. A composition of Halévy and organ student of Benoist, Batiste became a professor at the Conservatoire at an early age, taking on teaching duties at the age of seventeen before he had even finished his studies. ${ }^{4}$ Ochse relates that Batiste's "primary teaching areas were solfege, harmony, and vocal ensemble classes; his twelvevolume edition of Solfeges du Conservatoire was an important contribution to pedagogy." Batiste worked as organist at Saint-Nicolas-des-Champs 1842-54, and then at Saint-Eustache from 1854 until his death in 1876 . He was known as a great improvisor as well as a performer of the music of Bach, Mendelssohn, and other German masters. ${ }^{6}$ He published a number of compositions for the organ and was very active as a recitalist at organ premiers. "No organist in France was more visible," Ochse maintains, "and Batiste seems to have been unusually successful in bridging the chasm between the 'severe' players and their more popular colleagues." "

4 François-Joseph Fétis and Arthur Pougin, Biographie universelle des musiciencs et bibliographie générale de la musique: Supplément et Complément vol. 1, (Paris: Firmin Didot Frères, 1881), 52.

5 Ochse, Orpha. Organists and Organ Playing in Nineteenth-Century France and Belgium. (Bloomington, IN: Indiana University Press, 1994), 60.

6 Ibid.

7 Ochse, Organists and Organ Playing, 74. 
"Ave Maria"

1. Text:

2. Voice Part:

3. Key:

4. Range:

5. Tessitura:

6. Style:

7. Vocal Characteristics:

8. Keyboard Characteristics:
Full text of the Ave Maria is set with minimal repetition.

Soprano, tenor, or baritone.

B-flat Major.

D4 - E5.

A4 - B-flat4.

Lyric operatic style.

Short, legato phrases, regular leaps of no more than a fifth. Some agility required.

The organ accompaniment is easily playable on the manuals alone. There are registration markings which chiefly indicate when to use the solo oboe stop on the Récit. division.

9. Important Musical Elements: Varied accompaniment textures and registration changes.

10. Potential Uses:
The motet partakes of the popular nineteenth century style too much to find much success in liturgical use. It would be an enjoyable song to sing and could be useful for amateur singers or students developing legato line, as its limited range makes it accessible to the majority of singers.

Although Batiste did not list mezzo-soprano as one of the possible voice parts for the song, there is no reason why mezzo-sopranos could not sing it. 
"O Salutaris"

1. Text:

2. Voice Part:

3. Key:

4. Range:

5. Tessitura:

6. Style:

7. Vocal Characteristics:

8. Keyboard Characteristics:

9. Important Musical Elements:

10. Potential Uses:
Full first verse of the $O$ Salutaris is set, with some repetition, and no "Amen."

Tenor or soprano.

E-flat Major.

D4-G5.

A4-C5.

Bel canto style

Florid, bel canto lines; written out ornamentation (measures 7 and 11); consistent four bar phrases; some large interval leaps.

There are no particular markings regarding pedal or registration that would indicate that the accompaniment part is for organ. The score seems designed more for a generic keyboard instrument than specifically for the organ, with no idiomatic lines for pedal.

Textually, the setting is not particularly sensitive to the text. Lines of text are repeated at will and if there is any sense of text painting, it is through the expressiveness of the song as a whole.

The vocal line of this song was written for a singer of some skill and its operatic nature is probably enough to prevent it being used in the liturgy today. It could find a place in the teaching studio as a work for young tenors or perhaps for sopranos who need some repertoire that does not make demands on the high register. 


\section{François Bazin}

Born in 1816, François-Emmanuel-Joseph Bazin attended the Conservatoire de Paris, studying organ with Benoit and composition with Halevy. He distinguished himself in both disciplines, winning the first prize in organ in 1839 and first prize in composition in 1840. After three years of study and composition in Rome, he returned to Paris and became a professor of solfege at the Conservatoire. Over the next several years he had numerous operas produced at the Opéra-Comique, published a harmony textbook to use at the Conservatoire, and served as a member of the commission that supervised the teaching of singing at the Parisian municipal schools. ${ }^{8}$

8 Fétis, François-Joseph. Biographie universelle des musiciencs et bibliographie générale de la musique. (Paris: Firmin Didot Frères, 1866-1868), 281. 
"Pie Jesu"

1. Text:

2. Voice Part:

3. Key:

4. Range:

5. Tessitura:

6. Style:

7. Vocal Characteristics:

8. Keyboard Characteristics:

9. Important Musical Elements:

10. Potential Uses:
Full text of Pie Jesu, final statement is extended to "dona eis requiem sempiternam" (grant them everlasting rest) after the Requiem mass Agnus Dei.

Bass.

C minor.

G-flat2 - E-flat4.

G3 - B-flat3.

Sacred style.

Vocal line is mostly doubled; high notes are marked forte;

No pedal markings; part could be played on manuals without any adjustments until the very last chord, where the right hand has a span to reach of an octave and a fifth. Accompaniment is not particularly difficult.

Surprising chromaticism in measure 6; softened in measure 53 by the addition of a third voice. Final cadence in $\mathrm{C}$ Major is the only hint of nineteenth century sentimental piety.

This song is an interesting and welcome addition to the repertoire available for bass voice and could also be sung by a baritone with the interpolation of the low G-flat up an octave. Bazin's intent for the song could not be accurately represented in a transposition for high voice, and a mezzosoprano singing in the original key would cause the song to lose the gravitas that Bazin intended in writing for a bass. 


\section{François Benoist}

François Benoist (1794-1878) was one of the most influential organ teachers of the nineteenth century. A student at the Conservatoire de Paris, or École royale de musique as it was then called, he won the Prix de Rome in 1815. Upon returning from Italy in 1819, he was one of two organists awarded a position as organist at the Royal Chapel, and was also appointed professor of organ at the Conservatoire, both surprising appointments due to his young age. ${ }^{9}$ Benoist continued at the Conservatoire for the next fifty-three years, teaching many of France's most celebrated organists and composers, including Camille Saint-Saëns, Georges Bizet, Leo Delibes, Jules Massenet, Felix Danjou, Louis Lefébure-Wély, Théodore Dubois, and César Frank. ${ }^{10}$

Saint-Saëns relates that Benoist, although not a great organist, was a well-beloved and charming man, who was known as "Father Benoist." ${ }^{11}$ An "admirable teacher," Benoist would work at the orchestrations he was paid to supply to the Opera even while teaching lessons, yet he was able to "leave his work and make appropriate comments as though he had no other thought. ${ }^{12}$

Ochse, Organists and Organ Playing, 19

Ibid., 148

11 Ibid., 15

12 Saint-Saëns, Musical Memories, 16. 
"Ave Maria"

1. Text:

2. Voice Part:

3. Key:

4. Range:

5. Tessitura:

6. Style:

7. Vocal Characteristics:

8. Keyboard Characteristics:

9. Important Musical Elements:
Full text of Ave Maria. There is some repetition, but always with the words in order, not passed by and brought back later.

Mezzo-soprano.

C Major.

E-flat4 - E5.

G4 - B4.

Sacred style.

Simple two and four bar phrases; much of the vocal melody proceeds stepwise. The motet could easily be performed in the original key by baritones, and it would lose little in a transposition for higher voices.

Simple and devoid of pedal markings; eminently suitable for manuals alone, although perhaps a little dull at the piano with the loss of the organ's sustaining capability.

Points of harmonic interest correspond very exactly to points of textual expression, in a profoundly poignant way: E-flat seventh chord in measure 35 (see fig. 6) on the word "peccatoribus," (sinners); the G-sharp fully diminished seventh chord in measure 52 (see fig. 7) on the word "plena" (full).

Benoist's Ave Maria would be a welcome addition to the repertoire of amateur or beginning student singers and a reverent addition to the church repertoire even of advanced singers. 
"O Salutaris"

1. Text:

2. Voice Part:

3. Key:

4. Range:

5. Tessitura:

6. Style:

7. Vocal Characteristics:

8. Keyboard Characteristics:

\section{Important Musical Elements:}

10. Potential Uses:
First verse of $O$ Salutaris.

For one voice (unspecified).

A Major.

D-sharp4 - F-sharp5.

A4-B4.

Sacred style.

Legato phrases of two bars predominate, frequently outlining triadic harmonies. There are a fair number of large intervals to negotiate.

Engaging organ accompaniment. Only registration marking is in measure one: The note is positioned under the first note in the left hand, and the stem direction indicates that the entire moving figure in measures 1-3 is to be played by that solo flute. Italian dynamic markings and some fingerings by "Father Benoist," the teacher. There are no pedal markings, and the entire score is negotiable on manuals alone.

Repetition of musical phrases is well planned and lends a sense of direction. Repetition never occurs more than once; contrasting musical material is always natural, presented right away, and sometimes related to what has come before by inversion of direction or interval.

Range is negotiable for baritones and mezzo-sopranos, but more comfortable for tenor or soprano. Large intervals mean it is not appropriate for the beginning singer. Motet would nicely complement other Latin texted songs on a recital or may be greatly appreciated as a church solo. 


\section{Jules Cohen}

Like many of the composers represented in the pages of La Maîtrise, Jules Cohen (18301901) was a student at the Paris Conservatoire, studying under Halévy and Benoist. Cohen seems to have been no relation to Léonce Cohen, whose motet is also discussed in this paper. Jules Cohen was born in Marseilles, while Léonce was born in Paris. However, Jules also was a successful student at the Conservatoire. Champlin relates that Cohen was to have been a contestant for the Prix de Rome in 1855 but, being wealthy, when he found that he was a favorite to win, Cohen withdrew his name from consideration in favor of a needier student winning. The reward for this, Champlin says, was a professorship at the Conservatoire. ${ }^{13}$ Cohen held a professorship at the Conservatoire for thirty-five years, and was the chorus master at the Paris Opera for twenty years. ${ }^{14}$ Pougin describes Cohen rather coolly as a pianist and composer with little talent for composing works for the stage but who wrote some anyway, these having, at best, mediocre success. $^{15}$

13 John Denison Champlin and William Foster Apthorp, Cyclopedia of Music and Musicians, Volume 1 (New York: Charles Scribner's Sons, 1888), 338.

14 Dexter Smith, Lorin Fuller Deland, Thomas Tapper, Philip Hale, "Jules Cohen." Musical Record and Review, no. 470 (March 1901), 89.

15 François-Joseph Fétis and Arthur Pougin, Biographie universelle des musiciencs et bibliographie générale de la musique: Supplément et Complément vol. 1, (Paris: Firmin Didot Frères, 1881), 191. 
"O Salutaris"

1. Text:

2. Voice Part:

3. Key:

4. Range:

5. Tessitura:

6. Style:

7. Vocal Characteristics:

8. Keyboard Characteristics:

9. Important Musical Elements:

10. Potential Uses:
First verse of $O$ Salutaris.

Soprano or tenor.

A-flat Major.

E-flat4 - A-flat5.

B-flat4 - C5.

Lyric operatic style.

Vocal writing is lyrical. There are no opportunities for vocal "fireworks," either in terms of tricky melismatic passages or of virtuosic high notes. Instead, the melody is song-like and mostly syllabic, with no dialogue writing, and few long-spun phrases.

Accompaniment part is legato, chordal, and sustained. There are no musical figures idiomatic to the orchestra or piano. The score is playable on manuals alone.

Avoids many of the features of the popular, operatic style; musical language employed is mostly diatonic. While there is chromaticism, it is usually a way of approaching cadences, not a means of highlighting or creating drama. However, the text is freely repeated in a manner that does not exhibit a very serious understanding of the prayer.

With liturgical demand for the $O$ Salutaris not as high today as in the nineteenth century, church musicians will probably look beyond this setting by Cohen for an "O Salutaris" whose music has a more direct connection with the text. However, as a pedagogical tool, this motet offers some opportunities for training young tenors and sopranos. Many of the top notes come on open vowels, and the phrase containing the A-flat5 is a great chance for the voice to springboard up and over the passaggio. 


\section{Léonce Cohen}

Although he worked primarily as a violinist, Léonce Cohen was an organist and successful composer whose theatrical compositions found production opportunities on Parisian stages. A descendant of a well-to-do merchant family, Cohen attended the Paris Conservatoire, studied organ with Benoist, and also studied composition and violin. Although working as a violinist at the Comédie Italienne while still a student, his organ and composition studies earned him the 1852 Prix de Rome. Upon his return from Rome, he resumed working at the Comédie and also played at the Théâtre du Vaudeville. He had two operettas performed at the Thêatre des Bouffes-Parisiens, the first of which, Mam'zelle Jeanne was premiered in 1858, shortly after the publication of this "Ave Maria." 
"Ave Maria"

1. Text:

2. Voice Part:

3. Key:

4. Range:

5. Tessitura:

6. Style:

7. Vocal Characteristics:

8. Keyboard Characteristics:
Ave Maria prayer. Text "Mater Dei" omitted.

Tenor or soprano.

D-flat Major.

E-flat4 - A-flat5.

B-flat4 - E-flat5.

Bel canto style.

Bel canto writing designed to show off the range, legato, and dynamic control of the voice.

The organ accompaniment is straightforward, but an amateur keyboardist might have difficulty with it principally because of the key signature. Accompaniment is entirely pianistic in style, or rather, the style is that of a operatic orchestra reduction for piano, with as many as three different motives going on at once.

There are frequent dynamic markings from $p p$ to $f$ and many markings in Italian that would be common in opera scores (segue il canto, rallantando, dolcissimo, etc).

Requiring a wide range and frequent singing in and above the passaggio, this song is not for the beginning singer. Its operatic style will not be welcomed in church, and it is not likely to be programmed frequently on recitals, due to the abundance of Romantic era "Ave Marias" by more famous composers. However, its D-flat key signature is forgiving on singers looking to exercise their high A-flat5 with less taxing passaggio approaches (no G naturals). 


\section{François-Auguste Gevaert}

A native Belgian, François-Auguste Gevaert (1828-1908) was a pedagogue, composer, and musicologist who studied at the Ghent Conservatory. ${ }^{16} \mathrm{He}$ became a piano teacher and then an organist, but one of his compositions won the Belgian Prix de Rome in 1847. After completing his subsequent European travels, he settled in Paris, composing operas for the OpéraComíque where he served as music director from 1867-1870. The Franco-Prussian War prompted him to return to Belgium and upon François-Joseph Fétis' death in 1871, Gevaert succeeded Fétis as director of the Brussels Conservatory. Continuing the reform work Fétis had begun, Gevaert led the school for thirty-seven years and influenced music education throughout Belgium. ${ }^{17}$ As a pedagogue and musicologist, Gevaert was the author of a number of books, including works on orchestration, theory, liturgical chant, and organ technique, as well as editions of early music. ${ }^{18} \mathrm{He}$ was highly respected during his lifetime, and his compositions were fairly successful.

16 Anne-Marie Riessauw and Jean Hargot, "Gevaert, François-Auguste." Grove Music Online. January 01, 2001. Oxford University Press, accessed September 19, 2018, http:///www.oxfordmusiconline.com/grovemusic/view/10.1093/gmo/9781561592630.001.0001/omo9781561592630-e-0000011003.

17 Ibid.

18 Ibid. 
"O Salutaris"

1. Text:

2. Voice Part:

3. Key:

4. Range:

5. Tessitura:

6. Style:

7. Vocal Characteristics:

8. Keyboard Characteristics:

9. Important Musical Elements:

10. Potential Uses:
First stanza of $O$ Salutaris.

Unspecified (high voice).

E-flat Major.

E-flat4 - A-flat5.

B-flat4 - C5.

Lyric operatic style.

Wide range, wide dynamic contrasts: pp, f, p and ff all on the first page. Phrases are typically no longer than four bars, but typically require sustained, sensitive singing. Accompaniment is mostly chordal and organ-like; no markings for pedal, motet could be played on the harmonium, piano, or pipe-organ manuals.

Frequently featuring a walking descending bass line, the organ part interacts with the voice by doubling the melody in the highest voice; resting while the voice introduces a pedal tone; and providing occasional syncopation to increase dramatic and harmonic tension.

This is a well-constructed, interesting song. The craftsmanship evident in the melodic writing makes it appealing to sing, and the harmonic language - although chromatic and thoroughly romantic - is forthright and authentic. An interesting and perhaps forward-looking feature are the consecutive fourths in the first vocal phrase, a phrase which keeps recurring throughout the song. This could perhaps be a challenge piece for young singers but is more likely repertoire for the advanced or professional tenor or soprano. Transposition for lower voices is likely not a viable option, as the pitch would have to be lowered by at least a third for a comfortable baritone range due to the high tessitura. Motet is musically interesting and worth utilizing as a church solo or recital piece. 


\section{Fromental Halévy}

A talented musician from a young age, Fromental Halévy (1799-1862) became a student at the Paris Conservatoire at the age of eleven. By age twelve he was studying composition with Cherubini and in 1819, he won the Prix de Rome. After his Prix de Rome travels he returned to Paris, becoming a professor at the Conservatoire where he taught harmony, accompaniment, counterpoint, and fugue to such illustrious students as Gounod, Bizet, and Saint-Saëns. ${ }^{19}$ However, his greatest successes were as a composer of opera, and his "career as a composer is a history of success crowning early reverses, a success which he spent his life sustaining." 20 Macdonald describes Halévy's compositions as "fluent and professional... [owing] much to Italian music." ${ }^{21}$ His skill as an orchestrator was admired by Berlioz, and his operas were highly regarded by Wagner. ${ }^{22}$ With this pedigree, it is interesting that a work of his would appear in the pages of La Maitrise, especially one that is in the operatic style that seems contrary to Niedermeyer and d'Ortigue's aims. While many of the prominent opera composers alive in France at the time - such as Meyerbeer and Rossini - have works featured in the pages of $L a$ Maîtrise, Halévy was the only one to have an organ-accompanied solo motet featured.

19 Macdonald, "Halévy," Grove Music Online.

20 Ibid.

21 Ibid.

22 Ibid. 
"Ave Maria"

1. Text:

2. Voice Part:

3. Key:

4. Range:

5. Tessitura:

6. Style:

7. Vocal Characteristics:

8. Keyboard Characteristics:

9. Important Musical Elements:

10. Potential Uses:
Full text of Ave Maria.

Soprano.

A-flat Major.

C-flat4 - F5 (optional A-flat5).

A-flat4 - D-flat5.

Bel canto style.

Chromatic bel canto melody; vocal line is marked in twobar phrases but could be executed as longer phrases. Range and tessitura are not taxing for high voice.

Score is very pianistic and is not difficult. No registration markings, but pedal is marked as in measures 14-17. Similar places in the score - such as measures 24-30 - are not marked for pedal, however, it could be assumed. Small print pedal parts at the end of the motet indicate they are optional. These figures, and the rest of the accompaniment, could easily be negotiated on the manuals alone.

6/8 meter is characteristic of bel canto arias. Eighth note figure at the end of the song is unusual in organ repertoire, but common in opera orchestra scores or in song repertoire intended for piano.

From a pedagogical perspective, it offers the chance to teach Italianate purity of vowel within the context of French repertoire. The motet could be sung by an amateur or young singer, as the high A-flat at the end of the song is not necessary, and without it, the range and tessitura of the song are not taxing; in fact, the phrase beginning at measure 50 is quite low. While the song is marked for soprano, a mezzo-soprano or a tenor could also sing it. Because of its operatic nature, this "Ave Maria" may not be suitable for liturgical use, however, other than the preponderance of famous Ave Maria settings, there is no reason why it could not find a home on the recital stage. 


\section{A. Hénon}

Appearing in the same volume of La Maîtrise as the two anonymous "Sanctus Deus" settings, the "Pie Jesu" by Hénon could just as easily be listed under "Anonymous" today, for information on the author is largely unavailable. The score lists him as "A. Hénon, Organist of Saint-Eustache," but he was not the titulaire, as that position was held by Édouard Batiste from 1854. ${ }^{23}$ There seems to have been a person named Alexandre Hénon, but no biographical data was uncovered. Perhaps Monsieur Hénon played the choir organ or fulfilled organist duties in the absence of the titulaire. The organ at Saint-Eustache was notable in that it was the second new organ built for the church in a decade. Daublaine-Callinet, Cavaillé-Coll's main competitor, had built an organ for the church; it was premiered in 1844. Shortly thereafter, one of the organ's designers was inside the organ adjusting something and dropped his candle, causing a fire which destroyed the whole organ and threatened the church itself. ${ }^{24}$ However, by the time Batiste and Hénon were playing at Saint-Eustache, a new organ by Ducroquet had been built for the massive church. ${ }^{25}$

23 François-Joseph Fétis and Arthur Pougin, Biographie universelle des musiciencs et bibliographie générale de la musique: Supplément et Complément vol. 1, (Paris: Firmin Didot Frères, 1881), 52.

24 Ochse, Organists and Organ Playing, 41.

25 Ibid., 49. 
"Pie Jesu"

1. Text:

2. Voice Part:

3. Key:

4. Range:

5. Tessitura:

6. Style:

7. Vocal Characteristics:

8. Keyboard Characteristics:

10. Potential Uses:
Full of Pie Jesu, final statement is extended to "dona eis requiem sempiternam" (grant them everlasting rest) after the Requiem mass Agnus Dei.

For one voice (soprano).

D minor.

F4 - F5.

A-4 - C5.

Sacred style.

Very simple vocal line which proceeds almost entirely by step.

Organ part is not difficult: there are no indications for registration or pedal, and the entirety of the score can be played on manuals alone

9. Important Musical Elements: Long note values are a gesture toward the traditional sacred style; the regular use of 4-3 cadential suspensions is evocative of the church style.

This motet has doubtful applicability in the present time, especially with its authorship clouded in mystery. It could be used for the Church services, but only in the absence of other repertoires. In the teaching studio it will be neglected in favor of more interesting music, and outside of the church, it is unlikely to see any performance opportunities. However, such a performance was never within the scope of what this song was meant to do, and today, much as when it was published, it remains just a simple prayer for liturgical performance. 


\section{Edmond Hocmelle}

Pierre-Edmond Hocmelle (1824-1895) was "a blind organist who had won first prize in organ at the [Paris] Conservatory in 1846." An organ student of Benoist, Hocmelle also studied composition and composed throughout his life. Very popular in concert, Hocmelle "would become one of the better-known performers at organ inaugurations in the coming decades. ${ }^{226}$ In 1849 , he became organist at Saint-Louis-des-Invalides. ${ }^{27}$ However, he later took a position at Saint-Phillippe du Roule, where he oversaw the renovation of the organ by the Meklin firm, a competitior of Cavaillé-Coll, and a company that Hocmelle worked for as a house organist. Ironically, his Meklin instrument at Saint-Phillipe du Roule was replaced by an instrument from the Cavaillé-Coll firm in 1903. ${ }^{28}$

Hocmelle's "Tantum ergo" is the only organ-accompanied solo motet appearing in $\mathrm{La}$ Maîtrise setting that text. However, the text was a popular one with French composers, and there are other "Tantum ergo" settings in this genre by such luminaries as Fauré and Saint-Saëns.

César Franck wrote one for bass and optional chorus that is well known in the United States due to a variety of parings with English texts such as "Hear my cry, O God."29

6 Ochse, Organists and Organ playing, 46.

7 Ibid.

28 “Paris: Saint-Phillipe du Roule," Orgues France, accessed February 28, 2019, http://orguesfrance.com/ParisStPhilippeDuRoule.html.

29 César Franck and F. B. Melville. Hear My Cry, O God. (Boston, Mass: Boston Music Pub, 1913); César Frank, Tantum ergo. Paris: Pérégally and Parvy, 1865. 
"Tantum ergo"

1. Text:

2. Voice Part:

3. Key:

4. Range:

5. Tessitura:

6. Style:

7. Vocal Characteristics:

8. Keyboard Characteristics:

10. Potential Uses:
Both verses of the hymn Tantum ergo.

Bass.

F Major.

D3 - D4.

A-flat3 - B-flat3.

Sacred style.

Very simple vocal line which proceeds almost entirely by step.

No registration or pedal indications. The simple accompaniment is characterized by block chords in the right hand which parallel the vocal line; combined with a walking or arpeggiated bass line in the left hand, the score is playable on manuals alone

9. Important Musical Elements: Simple F Major harmonies - only broken by the plagal relationship of the B-flat Major sections - and simple, stepwise melody lines contribute an austere, reverential character to the song.

Benefield lists it as a solo motet, but it could easily be a unison motet for men's choir. ${ }^{30}$ Its narrow melodic compass, simple harmonies and chordal accompaniment place it much closer to congregational hymnody than solo vocal repertoire. It could be used pedagogically to teach legato line and Italianate vowels for a beginning singer but would probably find no other use in the pedagogical or professional vocal world. It would be most useful in the Catholic church music world, either at Benediction services, or as a Eucharistic motet sung by amateur soloist, or amateur parish choir. In either instance, it would not need to be restricted to bass or even male voices, as the D $\mathrm{D}$ range is typical of congregational hymnody.

30 Richard Benefield, Motets for one voice: the organ-accompanied solo motet in nineteenth-century France (Middleton, Wisconson: A-R Editions, 2003), xii. 


\section{Louis Lefébure-Wély}

Louis-James-Alfred Lefébure-Wély (1817-1869) was a celebrated composer and organ performers. The son of the titulaire at Saint-Roch, Paris, Lefébure-Wély first played for mass in 1826 at the tender age of eight years and four months. Not long after, his father became paralyzed in his left side, and young Louis took over all the playing at Saint-Roch, becoming the titulaire himself at age $14 .{ }^{31} \mathrm{He}$ was an early friend of Cavaillé-Coll and was frequently the latter's first choice as a recitalist for inaugural concerts on new organs ${ }^{32}$ Lefébure-Wély was instrumental in getting a Cavaillé-Coll organ for Saint-Roch in 1842, and Cavaillé-Coll helped Lefébure-Wély get the more lucrative position at the church of the Madeleine later on.

Lefébure-Wély rarely played written music, carrying on the long French improvisatory tradition which, by the nineteenth century, had incorporated many operatic elements and often featured dramatic contrasts and programmatic devices such as storm scenes, even in liturgical alternatim versets. When playing on the inaugural recital for Cavaille-Coll's first Parisian organ at the age of 21 , it was already noted that Lefébure-Wély played in a "light style" and that his music would improve by letting the works of great composers, such as the Germans Bach and Handel, influence his playing. ${ }^{33}$ The name Lefébure-Wély came to represent all "players of the popular or light type" of music, contrasted with the players of the "serious or severe type:" professor Benoist, or Jacques-Nicolas Lemmens and the Belgian school, known for their performances of the pedal-heavy music of J.S. Bach and other Germans. ${ }^{34}$

\footnotetext{
Ochse, Organists and organ playing, 20-21. Ibid., 28.

Ochse, Organists and organ playing, 32-33.

Ibid., 33.
} 
"O Salutaris"

1. Text:

2. Voice Part:

3. Key:

4. Range:

5. Tessitura:

6. Style:

7. Vocal Characteristics:

8. Keyboard Characteristics:

10. Potential Uses:
First stanza of $O$ Salutaris.

Bass.

E-flat Major.

B-flat2 - E-flat4.

B-flat4 - C5.

Sacred style.

Eight high E-flat4s, restricting the song to an advanced bass singer, or to baritones. The vocal line is almost always doubled in the accompaniment, but frequently by an inner voice. Regularly, the doubling does not extend to the vocal part's rhythms or octave. While the phrases are not particularly long, there is often little rhythmic interest in the vocal line, and nothing in the accompaniment to encourage the singer to maintain a sense of forward energy.

Chordal, idiomatic to the organ, with long sustained notes, particularly in the bass. Registration indications call for particular contrasting flute stops in the Grand Orgue and the Positif; the score directs when each are to be played. Directions are limited; after measure 28, "positif at will."35 No pedal markings; score can be played on manuals alone.

9. Important Musical Elements: Lefébure-Wély's "O Salutaris" for bass voice is perhaps surprising, because it is very much in the "serious," rather than popular, style. Alla breve time signature; features many "white notes," reminiscent of printed Renaissance choral scores.

The chromatic harmony may translate to modern ears as dated or trite. Song may not offer a lot of interest to modern performers, but it is a piece with characteristic writing for bass voices - slowly moving vocal lines, and descending arpeggios - which could prove useful for pedagogues or for singers building a sacred music recital.

35 "Positif a volonte," author's translation. 


\section{Armand Limnander}

Listed on the score simply as Limnander, the composer of the only solo setting of the text Salve Regina appearing in La Maîtrise is most probably this was Armand Limnander de Nieuwenhove (1814-1892), a Belgian musician who was very active in Paris before and during the publication of La Maitrise. Limnander was born at Ghent and studied at the Jesuit College in Fribourg, Switzerland. His music professor there was Fr. Louis Lambillotte, a Jesuit priest who was the first French scholar of Gregorian chant and a prolific composer. ${ }^{36}$

Upon completing his studies, Limnander moved back to Belgium and became known as the director of an award-winning Belgian choir, for which he wrote many choral works. Desirous to compose for the theater, he approached François-Joseph Fétis for some composition lessons and then, armed with letters of introduction from Fetis, moved to Paris to work and compose for the Parisian theaters. In Paris, Limnander continued to direct choirs, introducing a choral effect unkown in France: a solo song accompanied by a humming chorus. ${ }^{37}$ His operas were performed at the Théâtre Lyrique and at the Opéra-Comique and he had several large scale choral works were performed in Belgium. ${ }^{38}$ Fétis strongly gives the impression that Limnander was his protégé. He mentions having given Limnander composition lessons, gives personal reviews of premiers of Limnander's work, and takes pains to attribute the lack of productions of his work to causes other than the merit of the works themselves. ${ }^{39}$

36 John Young, "Louis Lambillotte." The Catholic Encyclopedia. Vol. 8 (New York: Robert Appleton Company, 1910) accessed January 10, 2019, http://www.newadvent.org/cathen/08759b.htm.

37 François-Joseph, Biographie universelle des musiciencs et bibliographie générale de las musique, vol. 5 (Paris: Firmin Didot Frères, 1866-1868), 303.

38 Ibid.

39 Fetis, Biographie vol. 5, 302-303 
"Salve Regina"

1. Text:

2. Voice Part:

3. Key:

4. Range:

5. Tessitura:

6. Style:

7. Vocal Characteristics:

8. Keyboard Characteristics:

9. Important Musical Elements:

10. Potential Uses:
Full text of Salve Regina.

For one voice (unspecified).

C minor.

C4 - E-flat5 (optional G5).

A-flat4 - B-flat4.

Sacred style.

Lyrical phrases requiring legato singing. Some four or fivebar phrases.

Simple organ part; no pedal markings, entire piece could be played on the manuals with the possible exception of the span of an octave and fifth in the left hand on the penultimate chord. The accompaniment is chordal, designed with the organ in mind, rather than the piano.

Opening vocal theme is obviously a quote of the famous "Pieta Signore," ostensibly by Stradella, but quite probably by Fétis. ${ }^{40}$

Figure 2.1. Principal theme

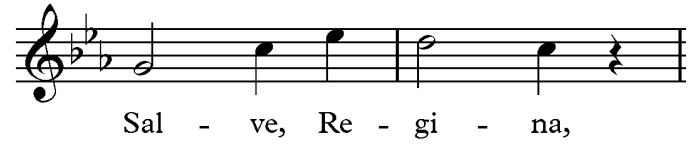

This motet is very accessible for sopranos and tenors, especially without the optional G5. Tessitura is varied throughout the song. This piece is interesting enough to be useful today: it is through composed; variety of melodic material; attractive parallel phrases structure. Could be used as solo work for churches or as a useful pedagogical piece for mezzo-sopranos and young tenors and sopranos. In this key, only suitable for advanced baritone voices.

Transposition would be welcomed by baritones and necessary for bass voices.

40 John Glenn Paton, 26 Italian Songs and Arias: Medium High Voice (Alfred Music, 2005), 138. 


\section{Charles Magner}

Charles Magner, the author of an "Ave Maria" found in La Maîtrise, is described on the score as a "student of the school of religious music of Paris." ${ }^{41}$ Fétis confirms that this school was in fact the École Niedermeyer, and that after receiving his training at this institution, Charles Magner (?-1893) went on to become "a pianist, composer, and teacher."42 After his studies, Magner became maître de chapelle for the church of Saint-Nicholas-du-Chardonnet, the college Rollin, and the Petit-Séminaire. Known mostly as a composer of motets and masses, Magner also wrote a small collection of songs and chamber music, and had a few light operas presented onstage. ${ }^{43}$ Very little additional information is available about Charles Magner, and as his date of birth seems to be unconfirmed, it is difficult to ascertain his age at the time this "Ave Maria" was published in La Maîtrise in 1857. While there is not really a distinctive compositional voice evident in the song, Magner's piece is a carefully constructed work, composed in the serious, contrapuntal style - musical evidence of the composer's studies at l'École Niedermeyer.

41 "Elève de l'ecole de musique religieuse de Paris." - translation by the author; François-Joseph Fétis and Arthur Pougin, Biographie universelle des musiciencs et bibliographie générale de la musique: Supplément et Complément vol. 2, (Paris: Firmin Didot Frères, 1881), 146.

42 Ibid.

43 Ibid., 146-147. 
"Ave Maria"

1. Text:

2. Voice Part:

3. Key:

4. Range:

5. Tessitura:

6. Style:

7. Vocal Characteristics:

8. Keyboard Characteristics:

9. Important Musical Elements:

10. Potential Uses:
Full text of Ave Maria. Some repetition.

Mezzo-soprano or baritone.

A Major.

E4 - E5.

A4 - C-sharp5.

Sacred style.

The melody calls for legato singing and has no climactic high notes. There are some large interval leaps, particularly the octave in measure 17.

Organ part is contrapuntal, almost entirely in four voices. Regular markings for "Pedal" and "S. Pedal" (senza pedal). Accompaniment manageable on manuals alone. One registration marking, "jeux doux;" in French organ tradition this indicates "a soft stop of a quiet registration."44 Dynamic and tempo markings are in Italian and are not numerous.

Two "Amens" which are notable for their plagal harmonic motion: affective, as the IV chord had been omitted thus far in the song. This gives the ending of the song a new color, a sense of having arrived at a new destination, and a sense of finality, all through the use of a chord diatonic to the key signature which had never been used.

Although this song is marked for low voices, it could easily be sung in the original key by higher voices and could especially be useful for those who have not developed their high notes. It would also be accessible by amateur singers who have enough musical sophistication to negotiate the song. With its limited range, Magner's "Ave Maria" could also be used as a unison choral anthem for church choirs.

44 Roger E. Davis, The Organists' Manual (New York: W.W. Norton and Company, 1985), 204. 


\section{Louis Niedermeyer}

The first organ-accompanied solo motet published in La Maîtrise was composed by its founderdirector, Louis Niedermeyer (1802-1861). As one of the most influential French musicians of the nineteenth century, there is a certain irony in that Niedermeyer was neither French, nor did he study in France. Niedermeyer was born in Switzerland in 1802 and his first music studies were in that country with his father. However, before the age of 20, he had studied in Vienna, Rome, and Naples, had befriended Rossini, had an opera produced and, most importantly for church music history, had been exposed to Renaissance polyphony. ${ }^{45}$

With the encouragement of Rossini, Niedermeyer moved to Paris and pursued a career of teaching and composing. Several of his operatic works were produced on Parisian stages. Unfortunately, none of these productions were a success, and after the last operatic failure in 1853, Niedermeyer turned to music pedagogy and sacred music for the rest of his career. He reopened Choron's earlier music school as the École de Musique Religieuse et Classique where, as Dyer relates, "students were schooled in Gregorian chant, the music of Palestrina and organ music, especially Bach."46 Along with his influential treatise on the accompaniment of Gregorian chant which he authored with Joseph d'Ortigue, his school, the École Niedermeyer, as it came to be called, became his lasting imprint on music, producing such illustrious graduates as Saint-Saëns, Fauré, and Gigout.

45 Guy Ferchault and Jacqueline Gachet, "Niedermeyer, (Abraham) Louis." Grove Music Online, January 01, 2001, Oxford University Press, accessed September 19, 2018, http:///www.oxfordmusiconline.com/grovemusic/view/10.1093/gmo/9781561592630.001.0001/omo9781561592630-e-0000019919.

46 Joseph Dyer, "Roman Catholic church music." Grove Music Online. January 01, 2001, Oxford University Press, accessed September 19, 2019, http:///www.oxfordmusiconline.com/grovemusic/view/10.1093/gmo/9781561592630.001.0001/omo9781561592630-e-0000046758. 
"Ave Maria"

1. Text:

2. Voice Part:

3. Key:

4. Range:

5. Tessitura:

6. Style:

7. Vocal Characteristics:

8. Keyboard Characteristics:

9. Important Musical Elements:

10. Potential Uses:
Full text of Ave Maria.

For soprano or tenor.

C Major.

E4-G5.

B4 - C5.

Sacred style.

Vocal line is bel canto as it is dramatic. There are frequent passages of repeated notes as well as much step-wise motion. However, with a few exceptions, the phrases are quite short.

An assigned pedal part is notated throughout the song. There are no registration markings and the pedal part is noted entirely in small type, indicating that the accompaniment was constructed to allow some flexibility in the choice of accompanying keyboard instrument.

There are optional parts for ATB which are not difficult, but are probably most useful only if the solo part is sung by a soprano. There is no soprano choral part.

This song is unlikely to be adopted for pedagogical purposes due to its length and the multitude of popular Ave Maria settings. It could prove useful for church soloist and choir. It could also be utilized on an undergraduate soprano voice recital by a student that wishes to involve some of her colleagues in her recital by singing the chorus parts. 
"O Salutaris I"

1. Text:

2. Voice Part:

3. Key:

4. Range:

5. Tessitura:

6. Style:

7. Vocal Characteristics:

8. Keyboard Characteristics:
First verse of $O$ Salutaris.

For soprano or tenor.

G minor.

F4 - A-flat5.

B-flat4 - D5.

Sacred style.

Wide range; large octave leap in measures 30 and 34; vocal line is dramatic in nature with frequent repeated notes. Phrases are typically short, but require sustained singing.

Numerous pedal markings. Pedal notes are written in small type. All of the small notes are doubled elsewhere and could be left out without affecting the harmony if played on manuals alone. Brief oboe stop solo in measure 33 .

9. Important Musical Elements: Option to take G4 or G5 at the end of the vocal line.

10. Potential Uses:
This piece could be useful for introducing non-operatic dramatic repertoire to a young voice. Advanced singers may also find it an interesting challenge. This motet deserves a place in at least the church repertoire, if not also in the concert hall. 
"O Salutaris II"

1. Text:

2. Voice Part:

3. Key:

4. Range:

5. Tessitura:

6. Style:

7. Vocal Characteristics:

8. Keyboard Characteristics:

9. Important Musical Elements:

10. Potential Uses:
First verse of $O$ Salutaris.

For soprano or tenor.

G Major.

F-sharp4 - F-sharp5.

B4 - D5.

Sacred style.

Sustained singing at a slow tempo. Some agility required for sixteenth notes. Range is not challenging, but tessitura frequently lies in the passaggio.

This is the only solo motet in La Maitrise to feature a three staff organ part. The pedal part mostly doubles the lowest voice in the left hand. However, it adds some contrasting rhythmic texture as well as additional bass sound, although its registration is not specified. Registration indications consist of markings for an oboe stop on the Recit. which is contrasted with an unspecified registration on the positif contrasting in ripieno style.

Vocal melody in measure 5 is an almost exact quote of the first measure of the vocal line from the chorus "For unto us a child is born," from Handel's Messiah. Niedermeyer references this in a note at the top of the score, stating that the first measure from a Handel chorus serves as the theme for the motet, but not naming the reference exactly. 47

This song offers a variety of pedagogical opportunities. Many of the high notes are on [i] vowels, a beneficial vowel for blending head and chest registers. Phrases are short, with notated rests. Tessitura and repeated F5s would prove challenging to young singers. This song would make an interesting selection for a recital, paired with an aria from Messiah.

47 "La première mesure d'un choeur de Haendel a servi de sujet pour ce motet," author's translation 


\section{Rubini}

Despite an investigation of major sources that supply biographical information on composers, no biographical information was uncovered on D. Rubini, the composer of the twenty-first solo motet published in La Maîtrise, an "Ave Maria” in F Major. The song was also published by G. Schirmer in 1875 with the addition of an English text for singing, but otherwise, exactly the same. ${ }^{48} \mathrm{G}$ Schirmer also published an "O Salutaris" by D. Rubini which is similar in style, but with a higher and more difficult vocal line and a slightly more interesting accompaniment than the "Ave Maria."49

48 D. Rubini, Ave Maria. (New York: G. Schirmer, 1875), accessed February 27, 2019, https://www.loc.gov/item/sm1875.14005/.

49 D. Rubini, O Salutaris. (New York: G. Schirmer, 1875), accessed February 27, 2019, https://www.loc.gov/item/sm1875.14006/. 
"Ave Maria"

1. Text:

2. Voice Part:

3. Key:

4. Range:

5. Tessitura:

6. Style:

7. Vocal Characteristics:

8. Keyboard Characteristics:

9. Important Musical Elements:

10. Potential Uses:
Full text of Ave Maria.

Soprano.

F Major.

C4 - F5.

A4-B4.

Sacred style.

The vocal melody features some chromaticism, text painting (measures 57-59), and passages set to one note (measures 79-83 and 102-109). Three measures of F natural are requested in measures 121-124 but measures 121-122 contain a lower alternative melody.

There are no markings for pedal or registration. However, the stem directions of the introduction indicate solo stop and pedal and accompaniment.

In the first portion of the song, the predominate accompaniment texture is of half note chords in the right hand and a quarter-note bass line in the left hand which continually covers an octave in one measure. In measure 77 the accompaniment texture changes with a single quarternote in the left hand, and an eighth-note figure in thirds in the right hand.

Could be used in church repertoire as a solo or a piece for unison choir. For the teaching studio, the motet could perhaps be useful as a piece for beginning singer, as there are few technical challenges. 


\section{Valancour}

There are some discrepancies between information to be found on the score of the next song and information regarding it on the article portion of this edition of La Maittrise ( $3^{\text {rd }}$ Year, No. 2.) The first discrepancy is regarding the name of the composer, which the score lists as "L. Valancour," but the front page of the journal lists as "L. Valancourt" with a "t."

Unfortunately, no biographical information is available on either spelling. "Valancour" or "Vaillancourt" is a medieval Norman name commonly anglicized as "Smart." Spelling aside, reasonable surmises as to the identity of the composer would be that "L. Valancour(t)" was a Parisian music student, a priest, or a woman relative of someone associated with La Maîtrise. More imaginative guesses might include the possibility that it was someone with the last name of "Smart" that had a connection to French music, perhaps a relative of the prominent English

musicians Sir George Smart or his nephew Henry Smart, the latter of which is mentioned in a review of press coverage in the aforementioned volume of La Maîtrise. 
"Sub tuum praesidium"

1. Text:

2. Voice Part:

3. Key:

4. Range:

5. Tessitura:

6. Style:

7. Vocal Characteristics:

8. Keyboard Characteristics:

10. Potential Uses:
Full text of Sub tuum praesidium.

For one voice (mezzo-soprano or baritone).

F Major.

E4 - F5.

A4 - B-flat4.

Sacred style.

Vocal melody proceeds almost entirely by step; it is very static, especially in measures 10-17. There are no features that would present special difficulty for any voice part. F5s occur in two places, but do not have a challenging approach.

The organ part is simple: chordal, mostly diatonic, several times featuring only three voices. There are no pedal or dynamic markings and apart from the initial marking of "Lent," no expressive markings. This part would be manageable on any keyboard instrument.

9. Important Musical Elements: There is some confusion on what voice part is intended. The score says simply "for one voice," while the song listing on the front of the journal says "for mezzo-soprano or baritone." 50

As a composition, Valancour's motet appears in the Petit Maîtrise, intended for small churches or less skilled musicians. As a pedagogical piece, it could be used to teach legato line and Italianate vowels. It could also be used effectively in the liturgy as a simple, voluntary meditation piece or a unison anthem for treble choirs.

50 “À une voix," author's translation. 


\section{Amédée Vandenheuvel}

The Agnus Dei for soprano appearing in the pages of La Maîtrise is attributed to a mysterious “A. Vandenheuvel.” Such a person does not appear either in Grove or in Fétis' Biographie. However, a Madame Van den Heuvel does appear regularly in period documents as an active soprano performer. Born Caroline Duprez, Madame Van den Heuvel was the daughter of the celebrated French tenor Gilbert Duprez and followed her father into the world of opera,

marrying a violinist, Amédée Van den Heuvel who played in Parisian opera orchestras. ${ }^{51}$ Moving in the fairly small musical circles of nineteenth century Paris, it is not at all improbable that Amédée is the "A. Vandenheuvel” of La Maîtrise, especially when one takes into account the operatic nature of this "Agnus Dei."

51 Bialystok-Stavenuiter, "Notes on 'Caroline Duprez-Van den Heuvel and husband by Disdéri,"” accessed February 27, 2019, http://www.ipernity.com/doc/289583/20209323. 
"Agnus Dei"

1. Text:

2. Voice Part:

3. Key:

4. Range:

5. Tessitura:

6. Style:

7. Vocal Characteristics:

8. Keyboard Characteristics:
Full text of Agnus Dei.

Soprano.

C Major.

F-sharp4 (optional C4) - G5.

C5 - E5.

Lyric operatic style.

Vocal line offers some challenging singing for sopranos. There are several long phrases calling for excellent breath control (indicated by the slur between measures 17 and 18 and the slur between measures 46 and 47). Leaps of a seventh in measures 10,12, and 15; moving eighth note passages on all three pages of the score. The range is not particularly large, and does not make taxing demands on the soprano's upper range. However, the optional low C4 requires strong chest voice tones.

Accompaniment is pianistic and resembles the piano reduction of an orchestral score. Slightly chordal, perhaps in deference to the sustaining capability of the organ; no pedal part; the whole score can be executed with manuals alone; no registration markings. Plentiful expressive markings are in Italian.

9. Important Musical Elements: Chromatic harmonies abound in this motet, although the vocal melody is mostly diatonic.

This song could be useful for student singers. The vocal line is somewhat interesting, and not too taxing. The piece has a dramatic sense to it, and the accompaniment could easily translate to the piano. Its operatic features would prevent it from being very widely accepted in the church music world. 


\section{Anonymous}

There are two solo motets in La Maîtrise lack any composer attribution and are listed as by "Anonymous." They are grouped together here, but there is no indication that they were written by the same anonymous composer. Both motets are upon the text Sanctus Deus from the Good Friday liturgy. Both are simple, straightforward melodies in a minor modality and while

they follow Benefield's definition of solo motet, they could also be seen as a hybrid between solo motet and liturgical chant.

Benefield defines the motet in nineteenth century France as "any freely composed substitution for a portion of Divine Liturgy that was otherwise sung to plainsong formulas... or other monophonic settings from the extensive repertoires of the church." ${ }^{25}$ It is possible both of these pieces would fall into the latter category, rather than actually being considered new compositions. The main indication for this is the note under the "Anonymous" composer attribution, "Comtat Venaissin." Comtat Venaissin was a part of the Papal States in what is now France. It had belonged to the Popes since the thirteenth century and was governed by administrators send from the Vatican. Quite possibly, the melody of this motet was a liturgical melody from the Comtat Venaissin which Niedermeyer or another editor of La Maîtrise had collected and thought worthy of wider distribution. In La Maîtrise it is assigned "for one voice," but it is hard to say whether this means that it was to be a solo, or whether this is simply to differentiate it from part music with more than one vocal line: that is, for unison voices.

52 Benefield, Motets for one voice, xi 
"Sanctus Deus" - A minor

1. Text:

2. Voice Part:

3. Key:

4. Range:

5. Tessitura:

6. Style:

7. Vocal Characteristics:

8. Keyboard Characteristics:

9. Important Musical Elements:

10. Potential Uses:
Full text of Sanctus Deus.

For one voice (unspecified).

A minor.

D4 - E5.

G4 - A4 .

Sacred style.

Melody is simple and mostly diatonic, more congregational than soloistic.

Keyboard part is very simple and solely for support of the voice. It doubles the vocal part throughout. It is easily played on keyboards alone.

A note in the score says that the verset "Jesu Christe" is to be sung without accompaniment and indeed it is presented with no organ part. It has a melody similar to the rest of the motet, but with an E dorian modality that contrasts with the A minor flavor of the rest of the song. The note in the score continues to the effect that upon the conclusion of the "Jesu Christe" verset, there should be said an Our Father and then the motet should be repeated from the top up to five times. ${ }^{53}$

For modern usage, this song would have little applicability except as an anthem-motet in the Catholic liturgy. It could be rendered by either a soloist or a unison choir. It would not be sung as part of the Good Friday Adoration of the Cross liturgy as, by omitting the Greek, it does not conform to the liturgical books.

53 "Les Chantres chantent le Verset suivant sans accompanement; après quoi PATER NOSTER et Da Capo jusqu'a cinq fois." 
"Sanctus Deus" - D minor

1. Text:

2. Voice Part:

3. Key:

4. Range:

5. Tessitura:

6. Style:

7. Vocal Characteristics:

8. Keyboard Characteristics:

10. Potential Uses:
Full text of Sanctus Deus.

For one voice (unspecified).

D minor.

D4 - C5.

G4.

Sacred style.

Melody is simple and diatonic, except for an F-sharp in measure 23. The text is treated a bit differently than in the A minor "Sanctus Deus." The liturgical portion of the prayer is set straight though, comprising the first half of the motet. Beginning at measure 15, the second half of the motet sets the "Jesu Christe" portion, with "miserere nobis" repeated once.

There is no organ introduction. Doubling the voice throughout, the organ accompaniment is not idiomatic to the nineteenth century, but in an older, baroque style. At the "Jesu Christe" section on page two, the organ part has a string of suspensions reminiscent of stile antico counterpoint. In three or four voices, the accompaniment is easily playable on manuals alone by even the most amateur player.

9. Important Musical Elements: In the vocal line, there are again figures indicative of ornamentation. Triplets appear in measures 6 and 9 grace notes in measures 2 and 10 . In measure 10 particularly, the grace note is characteristic of baroque ornamentation, perhaps indicating the origin of this piece of music.

While an attractive melody, this motet would have little contemporary applicability except as an anthem-motet in the Catholic liturgy. It could be rendered by either a soloist, or a unison choir. It would not be sung as part of the Good Friday Adoration of the Cross liturgy as, by omitting the Greek, it does not conform to the liturgical books. 


\section{CHAPTER 4}

\section{CONCLUSIONS}

\section{Contemporary uses}

The organ-accompanied solo motets published in La Maîtrise vary greatly in terms of style and usefulness at the present time. A repertoire created by French church musicians, mostly keyboardists and composers, these songs were intended to fill an immediate need for solo literature for church use. They are the product of an era in which the French were struggling to find a distinct sacred musical language, a goal which would not be achieved until a generation later. These motets are of somewhat uneven quality. Some, particularly by Niedermeyer or his students, are serious and forward looking. Others are sentimental, miniature opera arias by famous theatrical composers. Still others are in the serious style, but are actually plain, simple liturgical music. For the first two volumes, the motets were apparently selected from the works of significant composers or were solicited from them for publication in the journal. Alternatively, motets for volumes three and four seem to have been submitted to a newly formed editorial board of the journal and approved by them for publication. It is interesting to note that after Niedermeyer left the journal after the first two years of publication, years three and four no longer featured many songs in the serious, forward looking style of Niedermeyer. Instead, they were replaced music that is simple, functional, liturgical service music.

These latter motets can almost be seen as the French equivalent of the German Cecilian movement. Much like the French church music reform movement, the Cecilians "by... journalistic activities, [and] music editions... promoted the revival of Gregorian chant and Renaissance a cappella polyphony, the creation of original compositions inspired by the 
Renaissance repertory... and dignified organ music." ${ }^{11}$ Led by composers such as Kaspar Ett (1788-1847), Johann Caspar Aiblinger (1779-1867), Franz Xaver Witt (1834-1888), and Franz Xaver Haberl (1840-1910), the Cecilian movement never captured the imagination of first rate German composers in the same manner as the French church music reform captured the imagination of composers of the stature of Franck, Saint-Saëns, and Widor. "The Cecilians," says Dyer, "never quite addressed the issue of quality; thus their programme of reform tended to stress the absence of objectionable features rather than the presence of aesthetically outstanding ones." As Saint-Saëns maintained, "in art, holiness is not sufficient. Talent is necessary. Style is necessary." ${ }^{3}$ Some of the songs discussed here actually note that the vocal line should be sung "piously," and seem to be composed in the hope that their "holiness" or lack of "objectionable features" would obscure their lack of imagination.

As noted above, the most imaginative motets in the collection are those of the Niedermeyer school. These songs are meant to avoid the popular traits of contemporaneous music - they are not bel canto, operatic, or sentimental - and are more declamatory, serious, and dramatic (in the sense of vocal fach). The tension found in this collection between the Niedermeyer style and the operatic or sentimental style is the force that generated the emergence of modality. French composers of the late nineteenth and early twentieth centuries would go on to thoroughly explore modal harmony as an alternative to the sentimental, operatic past.

For contemporary use, three groups of musicians may wish to make use of these motets.

First among them would be soloists looking to sing the songs in their originally intended

1 Joseph Dyer, "Roman Catholic church music," Grove Music Online. 2001, Accessed September 19, 2018, http:///www.oxfordmusiconline.com/grovemusic/view/10.1093/gmo/9781561592630.001.0001/omo9781561592630-e-0000046758.

2 Dyer, "Roman Catholic church music."

3 Camille Saint-Saëns, "Music religieuse," École Buissonnière (Paris: Lafitte, 1913), 159-67; Quoted in Rollin Smith, Saint-Saëns and the Organ. (Stuyvesant, NY: Pendragon Press, 1992), 204. 
environment, the Catholic liturgy. The most appropriate songs for this use will be those that are in the serious style: the three motets by Niedermeyer; the "Ave Maria" and "O Salutaris" of Benoist; and the "O Salutaris" of Bazin. These are the most interesting and musically complex of the serious motets.

Another group of musicians who may wish to use these motets would be vocal pedagogues. Several of the songs could be used to enhance the vocal technique of young singers, as well as introducing them to Latin as a singing language, particularly the "Ave Marias" of Benoist and Batiste, which combine limited ranges with musical interest in a manner that would keep the interest of a young singer. Vandenheuvel's "Agnus Dei," probably too operatic for use in church, could also serve as an accessible song for young sopranos. The vocal line has a sense of drama and interest and the accompaniment could easily translate to the piano for concert performance. For a more challenging piece, Niedermeyer's "O Salutaris I" offers a style more fitting for a dramatic voice, with a slow tempo, impressive interval leaps, and sustained high notes. This motet could prove useful for introducing dramatic repertoire to a young voice without the connotations of opera.

Also interesting for vocal pedagogues are the three motets for bass voice, the "Pie Jesu" by Bazin, the "Tantum ergo" by Hocmelle, and the "O Salutaris" by Lefébure-Wély. As Alan Ord points out, bass singers often face "frustration" finding "music composed specifically for bass voice and music specifically composed for low voice which would be suitable for bass."4 Thus, additional repertoire for bass voices is always helpful, although the three motets listed above will not be appropriate for the beginning singer due to their high tessitura.

4 Alan J. Ord, Songs for Bass Voice: An Annotated Guide to Works for Bass Voice. (Metuchen, NJ and London: The Scarecrow Press, Inc., 1994), vii. 
A third group of musicians to whom these motets could prove useful would be those who wish to use these songs in recital. They will probably wish to draw from the songs mentioned above as church and pedagogical pieces, as these are some of the most interesting songs. However, they may also find some of the best operatic style songs - particularly the "Ave Marias" of Halevy and Batiste and the "O Salutaris" of the latter - will serve as appropriate vehicles for recital singing. Additionally, for those planning a recital group that uses themes or related compositions, Niedermeyer's “O Salutaris II" could be performed on a program that includes numbers from Handel's Messiah or that examines the impact of Messiah on subsequent composers.

\section{Future research}

In researching these songs, it became apparent that there are several related areas that present opportunities for further study. In Benefield's examination of organ-accompanied solo motets, he does not restrict himself to motets for one voice, but rather expands the genre to include motets for one or more soloists, as opposed to choral repertoire meant for multiple singers on each part. There are several pieces in La Maîtrise that could fall into that category. This project was restricted to the list of organ-accompanied solo motets that Benefield offered in his article, but the multi-voice motets of La Maîtrise are an area for further exploration. Multivoice solo motets would have to be distinguished from choral repertoire, and the relationship between the solo motets for one voice and those for more than one voice could be explored.

Another line of potential future research would be a project to re-engrave and publish the solo motets discussed in this paper. The principal part of Benefield's project was the creation of new engravings of works by Franck, Saint-Saëns, and Gounod. This collection of motets from $L a$ 
Maîtrise could also be newly engraved and published. Several of these motets are only available on microfilm via research institutions. It would be helpful to at least make a new edition of the best songs available to the public.

While the organ accompaniments of these motets have been very briefly examined in this document, a more thorough analysis of the scores by an organ scholar could be another related research topic. Someone versed in the solo organ repertoire of the composers discussed here could doubtless find connections between that literature and these solo motets.

Additional repertories of solo motets do exist and have yet to be examined. One collection to examine would be the twenty-six solo motets listed on the publisher's cover of Gounod's Trois Joli Motets faciles. Benefield provides a listing of these titles, but also warns that all of the settings "have not [yet] been located."5 As in La Maîtrise, Benefield mentions that the collection referenced on Trois Joli Motets faciles also contains duos and trios, but he does not provide a list of titles. However, like the La Maîtrise repertoire discussed above, these duos and trios could be examined as solo motets in contrast to choral repertoire.

Another line of related research would be to trace the influence of the French solo motet in the United States. It is clear that some of the French repertoire made it across the Atlantic, as the "Ave Maria" by D. Rubini examined here was published in the United States by G. Schirmer in 1875 , as was an addition solo motet on the text $O$ Salutaris. ${ }^{6}$ A study could be made solely of the solo motets published by G. Schirmer in the nineteenth century. A "Catalogue of Sacred Music published by G. Schirmer" appears on the back of the Rubini volumes and twenty-seven

\footnotetext{
Benefield, Motets for one voice, xi and xiii.

6 Rubini, D. Ave Maria. (New York: G. Schirmer, 1875), accessed February 27, 2019, https:/www.loc.gov/item/sm1875.14005/.

Rubini, D. O Salutaris. (New York: G. Schirmer, 1875), accessed February 27, 2019, https://www.loc.gov/item/sm1875.14006/.
} 
titles are for solo voice, several of them in Latin. A few of the composers are well known European masters, but many of the names are obscure. In addition to this list, the Library of Congress database contains additional motets published by G. Schirmer in the nineteenth-century that were not on previously mentioned lists, such as an "Ave Maria" by Polish composer Heinrich Panofka (1807-1887) and an "O Salutaris" by French composer Ernest Ryer (18231909).

A related research topic would be an examination of how the solo motet may have influenced composition for Protestant services, where vernacular and scriptural texts would have been a necessity, or how it may have influenced composition for Jewish synagogue services. This would be of especially interest in the United States, where Catholic, Protestant, and Jewish congregations existed side by side and where the same music publishing industry served both. Contemporaneously with the solo motets listed above - which were published in Latin/English editions - G. Schirmer was publishing English texted songs suitable for both Protestants and Catholics such as "My faith looks up to thee!" by German-born composer Robert Goldbeck and Balmer and Weber were publishing songs such as the Latin/English texted "O Jesu mi/Come unto him" by English composer Henry Leslie. ${ }^{7}$ A project on these songs might examine the manner in which the publishing industry dealt with the need for Latin texted songs for Catholic churches, English songs for Protestant churches, and Hebrew texted songs for Jewish services and how those needs influenced the composers who supplied the music.

\footnotetext{
7 Robert Goldbeck, My Faith Looks up to Thee, No. 4 Soprano. (New York: G. Schirmer, 1879), accessed March 7 , 2019, https:/www.loc.gov/item/sm1879.07242/; Henry Leslie, O Jesu mi - Come unto him. (Saint Louis: Balmer \& Weber, 1884), https://www.loc.gov/item/sm1884.18411/.
} 


\section{Final thoughts}

The motets of La Maîtrise offer a look into the fascinating world of nineteenth-century France. These motets illustrate the tensions that gave rise to some of the major developments in French music during the nineteenth century, including the French Romantic organ school, modal harmony, and the declamatory style which influenced art song and late-nineteenth century opera. Additionally, the songs present a variety of possible uses to vocal performers and pedagogues today. From introducing young singers to Latin diction to expanding the solo vocal literature available for the bass voice and church musicians, the motets of La Maîtrise are a versatile collection comprising only a portion of the organ-accompanied solo motet repertoire that is yet to be examined. With additional collections of motets to be examined and a variety of related topics and musical repertories, the organ-accompanied solo motets in La Maîtrise present a startingpoint for many lines of future research. A unique repertory, cultivated in a time or extraordinary change, the organ-accompanied solo motets of La Maîtrise are a compelling collection that is well worth investigating by the singing community. 
Bibliography

"Orphéon." Grove Music Online, 2001. Accessed February 24, 2019. http://www.oxfordmusiconline.com.www.libproxy.wvu.edu/grovemusic/view/10.1093/g mo/9781561592630.001.0001/omo-9781561592630-e-0000020492.

Benefield, Richard. Motets for one voice: the organ-accompanied solo motet in nineteenthcentury France. Middleton, Wisconson: A-R Editions, 2003.

Bennett, Peter. Sacred Repertories in Paris under Louis XIII. Farnam: Ashgate Publishing, Ltd., 2009.

Bergeron, Katharine. Decadent Enchantments: The Revival of Gregorian Chant at Solesmes. Berkeley: University of California Press, 1998.

Bialystok-Stavenuiter, "Notes on 'Caroline Duprez-Van den Heuvel and husband by Disdéri,"' accessed February 27, 2019, http://www.ipernity.com/doc/289583/20209323.

Bouzignac, Guillaume Bouzignac. O vere digna Hostia, ed Henri de Villiers (2001), accessed February 26, 2019, https://schola-sainte-cecile.com/ressourceschoristes/Bouzignac/OVereDignaHostia/OVereDignaHostia.pdf.

Brown, Howard Mayer, Ellen Rosand, Reinhard Strohm, Michel Noiray, Roger Parker, Arnold Whittall, Roger Savage, and Barry Millington. "Opera (i)." Grove Music Online. 2001. Accessed February 24, 2019.

http://www.oxfordmusiconline.com.www.libproxy.wvu.edu/grovemusic/view/10.1093/g mo/9781561592630.001.0001/omo-9781561592630-e-0000040726.

Caron, Augustin-Pierre-Paul. Manuel des Cérémonies selon le Rite de L'Église de Paris. Paris: Librairie d'Adrien le Clere et Cie., 1846.

Caswall, Edward. Lyra Catholica. New York: E. Dunigan and Brother, 1851.

Caswall, Edward. Hymns and Poems, Original and Translated. London: Burns, Oates \& Company, 1873.

Catholic Church. The Liber Usualis: with Introduction and Rubrics in English. Tournai, New York: Desclee Company, 1961.

Champlin, John Denison and William Foster Apthorp, Cyclopedia of Music and Musicians, Volume 1. New York: Charles Scribner's Sons, 1888.

Chartier, Yves. “Adrien de La Fage.” Musicologie.org, accessed November 7, 2018. http://www.musicologie.org/Biographies/l/lafage.html. 
d'Ortigue, Joseph. Dictionnaire liturgique, historique et theorique de plain-chant et de musique d'eglise. Vol.29 of Nouvelle Encyclopedie theologique, edited by l'Abbe Migne. Paris: J.P. Migne, 1853.

d'Ortigue, Joseph, and Louis Niedermeyer, editors. La Maîtrise. Paris: Heugel et Ce., 18571861.

d'Ortigue, Joseph. La Musique a l'eglise. Paris: Didier et Cie 1861.

Davis, Roger E. The Organists' Manual. New York: W.W. Norton and Company, 1985.

de Villiers, Henri. “The Sub Tuum Praesidium." New Liturgical Movement. Thursday, February 03, 2011. Accessed Jan. 24, 2019. http://www.newliturgicalmovement.org/2011/02/subtuum-praesidium.html\#.XDAdTS2ZPys.

Douglass, Fenner. Cavaillé-Colle and the Musicians. Sunbury Press: Raleigh, North Carolina, 1980.

Douglass, Fenner. The Language of the Classical French Organ. New Haven and London: Yale University Press, 1969.

Dyer, Joseph. "Roman Catholic church music." Grove Music Online. 2001. Accessed September 19, 2018.

http:///www.oxfordmusiconline.com/grovemusic/view/10.1093/gmo/9781561592630.00 1.0001/omo-9781561592630-e-0000046758.

Ellis, Katharine. Interpreting the Musical Past: Early Music in Nineteenth-Century France.

USA: Oxford University Press, November 10, 2005

Ellis, Katharine, Robert Wangermée, and Gustave Chouquet. "Fétis family." Grove Music Online. 2001. Accessed September 19, 2018.

http:///www.oxfordmusiconline.com/grovemusic/view/10.1093/gmo/9781561592630.00 1.0001/omo-9781561592630-e-0000009564.

Ferchault, Guy, and Jacqueline Gachet. "Niedermeyer, (Abraham) Louis." Grove Music Online. 2001. Accessed September 19, 2018, http:///www.oxfordmusiconline.com/grovemusic/view/10.1093/gmo/9781561592630.00 1.0001/omo-9781561592630-e-0000019919.

Fétis, François-Joseph. Biographie universelle des musiciencs et bibliographie générale de las musique. Paris: Firmin Didot Frères, 1866-1868.

Franck, César, and F. B. Melville. Hear My Cry, O God. Boston, Mass: Boston Music Pub, 1913.

Frank, César. Tantum ergo. Paris: Pérégally and Parvy, 1865. 
Gilbert, David. 2001 "Prix de Rome." Grove Music Online. Accessed February 19, 2019. http://www.oxfordmusiconline.com.www.libproxy.wvu.edu/grovemusic/view/10.1093/g mo/9781561592630.001.0001/omo-9781561592630-e-0000040632.

Goldbeck, Robert. My Faith Looks up to Thee, No. 4 Soprano. New York: Schirmer, G., 1879, accessed March 7, 2019, https://www.loc.gov/item/sm1879.07242/.

Gounod, Charles. 60 Chants Sacrés. Paris: Le Beau, 1878.

Gough, Austin. Paris and Rome: The Gallican Church and the Ultramontane Campaign 18481853. Oxford: Clarendon Press, 1986.

Grove, George, ed. “Ortigue, Joseph Louis D'” A Dictionary of Music and Musicians. London, New York: Macmillan and Co., 1900. Accessed 30 Sept. 2018.

https://en.wikisource.org/wiki/Page:A_Dictionary_of_Music_and_Musicians_vol_2.djvu/ 626

Henry. Hugh "Agios O Theos.” The Catholic Encyclopedia. Vol. 1. New York: Robert Appleton Company, 1907. Accessed February 27, 2019.

http://www.newadvent.org/cathen/01211b.htm.

Henry, Hugh. "Salve Regina." The Catholic Encyclopedia. Vol. 13. New York: Robert Appleton Company, 1912. Accessed January 102019. http://www.newadvent.org/cathen/13409a.htm.

Higgenbottom, Edward. "French Classical Organ Music and the Liturgy." Proceedings of the Royal Musical Association, vol. 103 (1976-1977), 19-40. Accessed August 28, 2018. https://www.jstor.org/stable/765884.

Huré, Jean. "The French School of Organ Playing in its Own Land." Translated by Frederick H. Martins. Musical Quarterly 6 (1920), 272-75.

Klotz, Hans, and Kurt Lueders. "Cavaillé-Coll, Aristide." Grove Music Online. 2001. Accessed February 27, 2019.

http://www.oxfordmusiconline.com.www.libproxy.wvu.edu/grovemusic/view/10.1093/g mo/9781561592630.001.0001/omo-9781561592630-e-0000005199.

Kimball, Carol. Song: A Guide to Art Song Style and Literature. Milwaukee, WI: Hal Leonard Corporation, 2006.

L'écuyer, Sylvia. "Ortigue, Joseph (Louis) d'." Grove Music Online. 2001. Accessed September 19, 2018.

http:///www.oxfordmusiconline.com/grovemusic/view/10.1093/gmo/9781561592630.00 1.0001/omo-9781561592630-e-0000020507.

Lennon, Joseph G. Preface to Batiste's Las Series of Voluntaries for the Organ. Edited by Joseph 
G. Lennon. Boston: Oliver Ditson, 1878.

Leslie, Henry. O Jesu mi - Come unto him. Saint Louis: Balmer \& Weber, 1884, accessed March 7, 2019, https://www.loc.gov/item/sm1884.18411/.

Locke, Ralph P. "Paris: centre of intellectual ferment." The Early romantic era: between revolutions, 1789 and 1848 . Edited by Alexander L. Ringer. Englewood Cliffs, NJ: Prentice Hall, 1991.

Lueders, Kurt. "Merklin, Joseph." Grove Music Online. 2001. Accessed February 26, 2019. http://www.oxfordmusiconline.com.www.libproxy.wvu.edu/grovemusic/view/10.1093/g mo/9781561592630.001.0001/omo-9781561592630-e-0000018451.

Lueders, Kurt. "Revisiting Parisian Organ Culture from the Long Nineteenth Century: Models for Renewal in a Challenging Context for Religion?" Liturgical Organ Music in the Long Nineteenth Century. Edited by Peter Peitsalo, Sverker Jullander, and Makus Kuikka. Helsinki: Sibelius Academy, University of the Arts Helsinki, 2017.

Macdonald, Hugh. "Benoist, François." Grove Music Online. 2001. Accessed September 19, 2018. http:///www.oxfordmusiconline.com/grovemusic/view/10.1093/gmo/9781561592630.00 1.0001/omo-9781561592630-e-0000002710.

Macdonald, Hugh. "Halévy, (Jacques-François-)Fromental(-Elie)." Grove Music Online. 2001. Accessed September 19, 2018.

$<$ http:///www.oxfordmusiconline.com/grovemusic/view/10.1093/gmo/9781561592630.0 01.0001/omo-9781561592630-e-0000012213>

Mershman, Francis. "Feast of Corpus Christi." The Catholic Encyclopedia. Vol. 4. New York: Robert Appleton Company, 1908. Accessed February 18, 2019. http://www.newadvent.org/cathen/04390b.htm.

Montagnier, Jean-Paul. "Da capo arias in French church music (ca. 1700-1760)." Musica e storia. 16, no. 3, January, 2008.

Montagnier, Jean-Paul. The Polyphonic Mass in France, 1600-1780. Cambridge: Cambridge University Press, 2017.

Niedermeyer, Louis and Joseph d'Ortigue. Gregorian Acccompaniment. Translated by Wallace Goodrich New York, London, Chicago: Novello, Ewer \& Co., 1905.

Ochse, Orpha. Organists and Organ Playing in Nineteenth-Century France and Belgium. Bloomington, IN: Indiana University Press, 1994.

Ord, Alan J. Songs for Bass Voice: An Annotated Guide to Works for Bass Voice. Metuchen, NJ and London: The Scarecrow Press, Inc., 1994. 
The Oxford Dictionary of Music. Oxford: Oxford University Press, 2012.

http://www.oxfordreference.com.www.libproxy.wvu.edu/view/10.1093/acref/9780199578 108.001.0001/acref-9780199578108-e-5736.

“Paris: Saint-Phillipe du Roule.” Orgues France. Accessed February 28, 2019. http://orguesfrance.com/ParisStPhilippeDuRoule.html.

Paton, John Glenn. 26 Italian Songs and Arias: Medium High Voice. Alfred Music, 2005.

Pius X. Moto propriu Tra Le Sollectitudine. Libreria Editrice Vaticana, 1903. Translated in the Adoremus Bulletin. Accessed September 20, 2018. https://adoremus.org/1903/11/22/trale-sollecitudini/.

Reeves, Anthony R. "The Use of French Latin for Choral Music." Choral Journal, 42 (October 2001), 9-15.

Riessauw, Anne-Marie, and Jean Hargot. "Gevaert, François-Auguste." Grove Music Online. 2001. Accessed September 192018. http:////www.oxfordmusiconline.com/grovemusic/view/10.1093/gmo/9781561592630.00 1.0001/omo-9781561592630-e-0000011003.

Rubini, D. Ave Maria. New York: G. Schirmer, 1875, accessed February 27, 2019, https://www.loc.gov/item/sm1875.14005/.

Rubini, D. O Salutaris. New York: G. Schirmer, 1875, accessed February 27, 2019, https://www.loc.gov/item/sm1875.14006/.

Sabatier, François. "Lemmens, Jacques-Nicolas." Grove Music Online. 2014. Accessed February 27, 2019.

http://www.oxfordmusiconline.com.www.libproxy.wvu.edu/grovemusic/view/10.1093/g mo/9781561592630.001.0001/omo-9781561592630-e-0000016384.

Saint-Saëns, Camille. 20 Motets. Paris: Durand, Schoenewerk et Cie., 1884. Musical score of Saint-Saens collected solo motets.

Saint-Saëns, Camille. Musical Memories. Tr. Edwin Gile Rich. Boston: Small, Maynard and Company, 1919.

Sanger, David. "Lefébure-Wély, Louis." Grove Music Online. 2001. Accessed September 19, 2018.

http:///www.oxfordmusiconline.com/grovemusic/view/10.1093/gmo/9781561592630.00 1.0001/omo-9781561592630-e-0000045840.

Smith, Dexter, and Lorin Fuller Deland, Thomas Tapper, Philip Hale, “Jules Cohen.” Musical 
Record and Review, no. 470 (March 1901).

Smith, Rollin. Saint-Saëns and the Organ. Stuyvesant, NY: Pendragon Press, 1992.

Streletski, Gérard. "Bazin, François-Emmanuel-Victor." Grove Music Online. 2001. Accessed September 19, 2018.

http:///www.oxfordmusiconline.com/grovemusic/view/10.1093/gmo/9781561592630.00 1.0001/omo-9781561592630-e-0000002396.

The Oxford Dictionary of Music. Oxford: Oxford University Press, 2012. Accessed February 27, 2019.

http://www.oxfordreference.com.www.libproxy.wvu.edu/view/10.1093/acref/9780199578 108.001.0001/acref-9780199578108-e-573.

Van Wye, Benjamin. "Organ Music in the Mass of the Parisian Rite to 1850 with Emphasis on the Contributions of Boëly." French Organ Music: From the Revolution to Franck and Widor. Edited by Lawrence Archbold and William J. Peterson. Rochester, NY: University of Rochester Press, 1995.

van Wye, Benjamin. "Ritual Use of the Organ in France." Journal of the American Musicological Society, 33, no. 2 (Summer, 1980), 287-325.

Williams, Peter. A New History of the Organ. Bloomington and London: Indiana University Press, 1980.

Young, John. "Louis Lambillotte." The Catholic Encyclopedia. Vol. 8. New York: Robert Appleton Company, 1910. Accessed January 10, 2019. http://www.newadvent.org/cathen/08759b.htm. 


\title{
APPENDIX A
}

\section{TEXTS AND TRANSLATIONS}

\author{
Ave Maria
}

Ave Maria, gratia plena

Dominus tecum.

Benedicta tu in mulieribus, et benedictus fructus ventris tui, Jesus.

Sancta Maria, Mater Dei, ora pro nobis peccatoribus, nunc et in hora mortis nostrae. Amen.
Hail Mary, full of grace the Lord is with thee. Blessed art thou amongst women, and blessed is the fruit of thy womb, Jesus.

Holy Mary, mother of God, pray for us sinners, now and at the hour of our death. Amen.

\section{O Salutaris Hostia}

A thirteenth century hymn by the Catholic Doctor, St. Thomas Aquinas, the $O$ Salutaris is the last two verses of the six stanza hymn Verbum supernum prodiens in honor of the Eucharistic sacrament. This text was quite popular in France, it having been the practice in Paris to sing it at the mass immediately following the consecration since at least the sixteenth century. ${ }^{1}$ It was also used as part of the service of Benediction of the Blessed Sacrament in both the Parisian and Roman Rites. St. Thomas' text is as follows:

O salutaris Hostia, Quæ cæli pandis ostium: Bella premunt hostilia, Da robur, fer auxilium.

Uni trinoque Domino Sit sempiterna gloria, Qui vitam sine termino Nobis donet in patria.
O Saving Victim! opening wide The gate of heaven to man below! Our foes press hard on every side; Thine aid supply, thy strength bestow.

To thy great Name be endless praise, Immortal Godhead, one in three! $\mathrm{Oh}$, grant us endless length of days, In our true native land with thee! ${ }^{2}$ 
The French often inserted a third verse between the other two. It is said to have been written by King Louis XII and was sung at his order with the approval of the clergy at the elevation of all high masses. ${ }^{3}$

O vere digna hostia Quae caeli pandis ostium In te confidit Francia Da pacem, serva lilium. ${ }^{4}$
O true and worthy Host which opens the door of heaven, We entrust France to you, Give peace, save the lily. ${ }^{5}$

\section{Pie Jesu}

Pie Jesu Domine dona eis requiem.
Merciful Lord Jesus, grant them eternal rest.

The Pie Jesu comes from the Requiem or Mass for the Dead. It is the ending of the Dies Irae sequence, which describes the day of judgment and the soul's faith Christ. In the Parisian Rite, the Pie Jesu was often sung as an elevation motet at Requiem masses. ${ }^{6}$

\section{Agnus Dei}

Agnus Dei, qui tollis peccata mundi, Lamb of God, who takes away the sins miserere nobis. of the world, have mercy on us.

Agnus Dei, qui tollis peccata mundi, Lamb of God, who takes away the sins miserere nobis. of the world, have mercy on us. Agus Dei, qui tollis peccata mundi, dona Lamb of God, who takes away the sins nobis pacem. of the world, grant us peace.

Part of the mass Ordinary, the Angus Dei occurs after the Canon of the mass and shortly before the communion

\section{Tantum ergo}

Villiers - translated by the author

Bennet page 129

Author's translation

6 Montagnier, Jean-Paul. "Da capo arias in French church music (ca. 1700-1760)." Musica e storia 16, no. 3 (January, 2008), 242. 
Tantum ergo Sacramentum

Veneremur cernui:

Et antiquum documentum

Novo cedat ritui:

Præstet fides supplementum

Sensuum defectui.

Genitori, Genitoque

Laus et iubilatio,

Salus, honor, virtus quoque

Sit et benedictio:

Procedenti ab utroque

Compar sit laudatio.
Down in adoration falling, Lo! the sacred Host we hail, Lo! o'er ancient forms departing Newer rites of grace prevail; Faith for all defects supplying, Where the feeble senses fail.

To the Everlasting Father, And the Son Who reigns on high

With the Holy Ghost proceeding

Forth from Each eternally, Be salvation, honour, blessing, Might, and endless majesty. ${ }^{7}$

Tantum ergo is the last two stanzas of the hymn Pange lingua gloriosi, composed by St. Thomas Aquinas as a Vespers hymn for the feast of Corpus Christi at the request of Pope Urban IV. ${ }^{8}$ The whole hymn is still used to this day in the Roman Rite for processions of the Blessed Sacrament on Holy Thursday and Corpus Christi, and the last two stanzas are sung as part of Benediction of the Blessed Sacrament which was a common and popular service in nineteenth century France.

\section{Sub tuum praesidium}
Sub tuum
praesidium
confugimus, sancta Dei Genitrix :
nostras deprecationes
ne despicias
in necessitatibus, sed a periculis cunctis libera nos semper, Virgo gloriosa et benedicta.

\author{
Under your \\ patronage \\ we take refuge \\ Holy Mother of God; \\ our petitions, \\ do not despise \\ in necessities, \\ but of all dangers \\ deliver us always \\ glorious Virgin \\ and blessed.
}

\footnotetext{
7 Caswall, p. 63-64

8 Francis Mershman, "Feast of Corpus Christi." The Catholic Encyclopedia. Vol. 4. (New York: Robert Appleton Company, 1908), accessed February 18, 2019, http://www.newadvent.org/cathen/04390b.htm.
} 
In France, the Sub tuum praesidium was quite popular. A medieval custom used the prayer instead of the Salve Regina as the last prayer of the liturgical day. This custom prevailed in several French diocesan rites - including the Parisian rite - until the nineteenth century. ${ }^{9}$ To the present day, it is used in connection with Benediction of the Blessed Sacrament. ${ }^{10}$

\section{Salve Regina}

Salve Regina Mater misericordiae, Vita, dulcedo, et spes nostra, salve. Ad te clamamus, exsules filii Hevae; Ad te suspiramus gementes et flentes in hac lacrymarum valle.

Eia ergo advocata nostra, illos tuos misericordes oculos ad nos converte. Et Jesum, benedictum fructum ventris tui, Turn then, $\mathrm{O}$ most gracious advocate, nobis post hoc exsilium ostende. $\mathrm{O}$ clemens, $\mathrm{O}$ pia, O dulcis Virgo Maria. ${ }^{11}$
Hail Holy Queen, mother of mercy, Our life, our sweetness, and our hope. To thee do we cry, poor banished children of Eve.

To thee do we send up our sighs, mourning and weeping in this vale of tears. thine eyes of mercy toward us, and show unto us the fruit of thy womb, Jesus. O clement, o loving, o sweet Virgin Mary. ${ }^{12}$

\section{Sanctus Deus}

Sanctus Deus, sanctus fortis, sanctus et immortalis miserere nobis.
Holy God, holy might one, holy and immortal one, have mercy on us.

Jesu Christe crucifixe miserere nobis. Jesus Christ crucified, have mercy on us. The text Sanctus Deus occurs in the Roman and Parisian Good Friday liturgies where it is sung during the Adoration of the Cross. ${ }^{13}$ The text is a translation into Latin of the Greek hymn Agios $O$ Theos, the Latin being sung in line by line alternation with Greek and the combination of the

9 Henri de Villiers, "The Sub Tuum Praesidium," New Liturgical Movement, February 3, 2011, accessed February 27, 2019, http://www.newliturgicalmovement.org/2011/02/sub-tuum-praesidium.html\#.XDAdTS2ZPys

10 Ibid.

11 Hugh - Catholic Encyclopedia

12 Traditional Catholic Prayer, supplied by author

13 Augustin-Pierre-Paul Caron, Manuel des Cérémonies selon le Rite de L'Église de Paris (Librarie d'Adrien le Clere et Cie., 1846), 208. 
two being sung between verses of the Improperia, or Reproaches. ${ }^{14}$ The line beginning "Jesu Christe" does not appear in the Roman liturgical books, and is perhaps a traditional, devotional addition.

14 Hugh Henry, “Agios O Theos,” The Catholic Encyclopedia. Vol. 1 (New York: Robert Appleton Company, 1907), accessed February 27, 2019, http://www.newadvent.org/cathen/01211b.htm. 